\title{
Factors Affecting the Compressive Strength of Geopolymers: A Review
}

\author{
Hengels Castillo 1,2,*(D), Humberto Collado ${ }^{1,2}$, Thomas Droguett ${ }^{3,4}$, Sebastián Sánchez ${ }^{3,5}$, Mario Vesely ${ }^{1}$, \\ Pamela Garrido ${ }^{3}$ and Sergio Palma ${ }^{2}$
}

check for

updates

Citation: Castillo, H.; Collado, H.; Droguett, T.; Sánchez, S.; Vesely, M.; Garrido, P.; Palma, S. Factors Affecting the Compressive Strength of Geopolymers: A Review. Minerals 2021, 11, 1317. https://doi.org/ $10.3390 / \min 11121317$

Academic Editors: Carlito Tabelin, Thomas N. Kerestedjian and Alexander Karamanov

Received: 13 October 2021

Accepted: 18 November 2021

Published: 25 November 2021

Publisher's Note: MDPI stays neutral with regard to jurisdictional claims in published maps and institutional affiliations.

Copyright: (c) 2021 by the authors. Licensee MDPI, Basel, Switzerland. This article is an open access article distributed under the terms and conditions of the Creative Commons Attribution (CC BY) license (https:/ / creativecommons.org/licenses/by/ $4.0 /)$.
1 JRI Ingeniería, Santiago 7770445, Chile; hcollado@jri.cl (H.C.); mvesely@jri.cl (M.V.)

2 Complex Fluids Laboratory, Department of Metallurgical Engineering and Materials, Universidad Técnica Federico Santa María, Santiago 8940572, Chile; sergio.palma@usm.cl

3 CIMS-JRI, Santiago 7850000, Chile; thomas.droguett@cimsjri.cl (T.D.); sebastian.sanchez@jri.cl (S.S.); pgarrido@cimsjri.cl (P.G.)

4 Department of Metallurgical Engineering, Universidad de Santiago de Chile, Santiago 9170022, Chile

5 Escuela de Ingeniería Química, Pontificia Universidad Católica de Valparaíso, Valparaíso 2340025, Chile

* Correspondence: hcastillo@jri.cl

\begin{abstract}
Geopolymers are created by mixing a source of aluminosilicates, which can be natural or by-products from other industries, with an alkaline solution. These materials based on by-products from other industries have proven to be a less polluting alternative for concrete production than ordinary Portland cement (OPC). Geopolymers offer many advantages over OPC, such as excellent mechanical strength, increased durability, thermal resistance, and excellent stability in acidic and alkaline environments. Within these properties, mechanical strength, more specifically compressive strength, is the most important property for analyzing geopolymers as a construction material. For this reason, this study compiled information on the different variables that affect the compressive strength of geopolymers, such as $\mathrm{Si} / \mathrm{Al}$ ratio, curing temperature and time, type and concentration of alkaline activator, water content, and the effect of impurities. From the information collected, it can be mentioned that geopolymers with $\mathrm{Si} / \mathrm{Al}$ ratios between 1.5 and 2.0 obtained the highest compressive strengths for the different cases. On the other hand, high moderate temperatures (between 80 and $90{ }^{\circ} \mathrm{C}$ ) induced higher compressive strengths in geopolymers, because the temperature favors the geopolymerization process. Moreover, longer curing times helped to obtain higher compressive strengths for all the cases analyzed. Furthermore, it was found that the most common practice is the use of sodium hydroxide combined with sodium silicate to obtain geopolymers with good mechanical strength, where the optimum SS/ NaOH ratio depends on the source of aluminosilicates to be used. Generally speaking, it was observed that higher water contents lead to a decrease in compressive strength. The presence of calcium was found to be favorable in controlled proportions as it increases the compressive strength of geopolymers, on the other hand, impurities such as heavy metals have a negative effect on the compressive strength of geopolymers.
\end{abstract}

Keywords: Si / Al ratio; curing; impurities; water/solids ratio; compressive strength

\section{Introduction}

A geopolymer is an inorganic synthetic polymer generated through the reaction between aluminosilicate materials and alkaline agents, where after curing a semi-crystalline amorphous material is generated [1]. The curing reaction can occur both at high temperatures and at room temperature, depending on the composition of the geopolymer [2].

There are a wide variety of aluminosilicate reagents that can be used to produce geopolymers. The most common sources of aluminosilicates used for the production of geopolymers are metakaolin and by-products from other industries such as fly ash, mine tailings, red mud, slags, etc. [3-10]. There are also studies on geopolymers based on volcanic ashes [11]. 
Geopolymer precursor materials, both in natural as well as by-product forms, are required to be rich in alumina $\left(\mathrm{Al}_{2} \mathrm{O}_{3}\right)$ and silica $\left(\mathrm{SiO}_{2}\right)$ content, preferentially in reactive amorphous form [3]. The role of these compounds is to impart the strength and setting property to the cement [12]. A concern related to aluminosilicate dissolution is the rate at which it occurs and how much of the total amorphous aluminosilicate material is available for geopolymerization [13].

In addition to the aluminosilicate reagent, an alkaline activator is needed to produce the geopolymer. The alkaline activator causes the dissolution of the raw materials [14]. It must be carefully selected because its composition has different impacts on the properties of fresh geopolymer paste and development of the mechanical strength in the hardened geopolymers [15]. The most common are alkali hydroxide and silicate solutions.

In the activation of the aluminosilicate source with $\mathrm{NaOH}$ (most commonly used alkaline reagent), the reaction starts with the dissolution of $\mathrm{Al}$ and $\mathrm{Si}$, which are precursor particles in the alkaline solution, and then, followed by polymerization in the aluminumrich first gel phase, which will be transformed into silicon-rich final geopolymer gel [16].

The product resulting from the reaction between the aluminosilicate source and the alkaline activator is an amorphous substance composed of solid phases of aluminosilicates armed based on connections of $\mathrm{SiO}_{4}{ }^{4-}$ and $\mathrm{AlO}_{4}{ }^{5-}$ as tetrahedra forming a 3D structure.

In short, geopolymerization is an exothermic process involving various oligomers and other structural units (three-dimensional structural units) that form macromolecular microstructures, which in turn determines the mechanical properties of geopolymers through numerous experimental and theoretical studies of reaction kinetics. Some researchers have proposed that the synthesis of geopolymers is composed of three steps in the following sequence (Figure 1): (i) the dissolution of aluminosilicate materials comprising silicate and aluminate monomers, (ii) the gel formation process involving the transformation of the active monomers into geopolymeric fragments of cross-linked aluminosilicate oligomers, and (iii) the formation of geopolymer gel through the chain reaction of crystallization and polymerization [17].

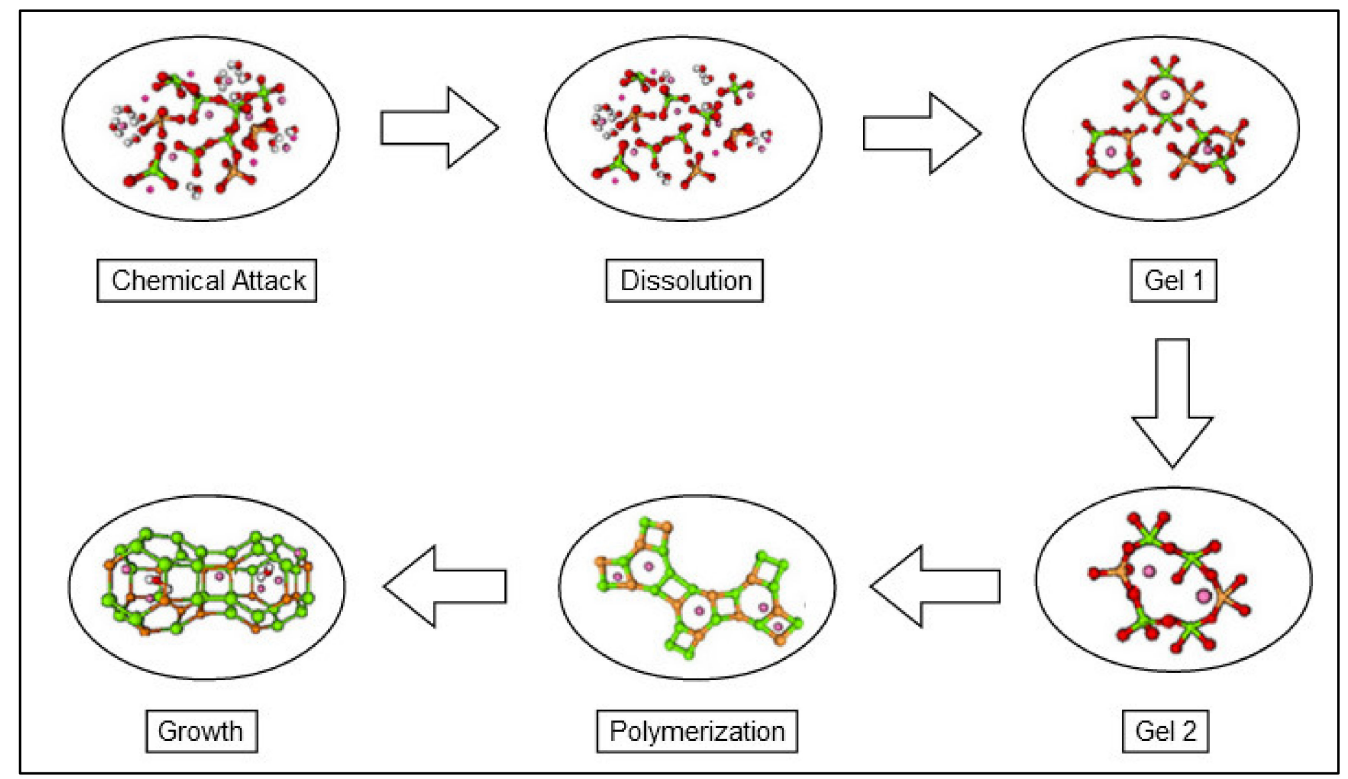

Figure 1. Conceptual design of the geopolymerization process.

The main hydration product of low-calcium or calcium-free binders is N-A-S-H gel, which possesses a three-dimensional structure [18]. The development of strength in geopolymers strongly depends on the raw materials and the alkali activator solutions [19]. 
In general, and from another point of view, geopolymers are a man-made material that offer several advantages, including good mechanical strength and the capacity to encapsulate hazardous waste, as well as being water and fire resistant.

Geopolymer is being studied extensively and shows promise as a greener alternative to Portland cement concrete [20]. Geopolymers use industrial by-products as precursors, and, therefore, result in the emission of significantly less $\mathrm{CO}_{2}$ per ton of concrete produced [21]. Geopolymer concrete (GPC) is estimated to reduce $80 \%$ carbon footprint in construction projects compared with ordinary Portland cement [22,23].

In order to build a geopolymer with a good compressive strength, different variables must be taken into account at the time of designing it, such as the type of aluminosilicate source, its composition, the composition and concentration of the alkaline activator, the amount of water to be used, whether it is cured at ambient temperature or by adding heat, among others. For this reason, the most important variables were considered when designing a geopolymer to obtain a good compressive strength, which were divided into $\mathrm{Si} / \mathrm{Al}$ ratio, temperature and curing time, alkaline activator, water content, and the effect of the presence of calcium and other impurities.

This paper compiles studies by several researchers, focusing mainly on the effect of the aforementioned variables on the compressive strength of geopolymers. Within the studies, different sources of aluminosilicates will be analyzed, geopolymers will be compared with classic materials such as OPC and also possible applications that have been given to geopolymers in recent years will be discussed, including their use as construction materials.

\section{Compressive Strength}

Geopolymer concrete has mechanical properties comparable to those of OPC concrete [19]. To use geopolymers as construction material, it is required that it must have good mechanical and volumetric stability [24], and especially a stable compressive strength so that the factors that have a major influence on this property will be compiled as indicated in the next chapters.

\subsection{Molar Ratios}

The early and final strength of the alkali activated materials depends on the design of the mixture ( $\mathrm{Si} / \mathrm{Al}, \mathrm{Al} / \mathrm{Na}$, water/Na ratio, etc.) and the reactivity of the components.

Lahoti et al. [25] showed the influence of four mix design parameters (Si/Al ratio, water/solids ratios, $\mathrm{Al} / \mathrm{Na}$ ratio and water/Na ratio) on compressive strength of metakaolinbased geopolymers synthesized. Figure 1 shows a clear trend, where the compressive strength increases with the $\mathrm{Si} / \mathrm{Al}$ ratio, peaks at $\mathrm{Si} / \mathrm{Al}$ ratio close to 2 and then decreases with increasing $\mathrm{Si} / \mathrm{Al}$ ratio afterwards. On the other hand, in the study of the water/solid ratio, the dependence of the compressive strength on this ratio was analyzed, where, in general, a decrease in compressive strength was observed with increasing water content, but large variations in compressive strength were also observed with the same water/solid ratio. This indicates that the water/solid ratio alone does not determine compressive strength of alkali activated geopolymers. The variation of the $\mathrm{Al} / \mathrm{Na}$ ratio showed that the highest compressive strength can be achieved when this ratio is close to one. Finally, it was observed that the water/Na ratio does not significantly influence the development of compressive strength. Further, the same author carried out an analysis to give quantitative information about the relative importance of the variables presented above. The results showed that $\mathrm{Si} / \mathrm{Al}$ ratio is the most important parameter followed by $\mathrm{Al} / \mathrm{Na}, \mathrm{H}_{2} \mathrm{O} / \mathrm{Na}_{2} \mathrm{O}$ and water/solid ratios. The $\mathrm{Si} / \mathrm{Al}$ ratio of the alkali activated materials mixtures cannot go below 1.0 as this is the lower limit for any geopolymer gel because the formation of $\mathrm{Al}-\mathrm{O}-\mathrm{Al}$ bonds is not favored [26]; however, there must be enough aluminum to have a stable aluminosilicate network, otherwise the dissolution of the excess silica will occur [27].

The study by Duxson et al. [28], in which the composition and microstructure of metakaolin-based geopolymers were studied, obtained a simple compressive strength of $75 \mathrm{MPa}$ with a $\mathrm{Si} / \mathrm{Al}$ ratio $=1.90$ using sodium silicate $\left(\mathrm{Na}_{2} \mathrm{SiO}_{3}\right)$ as an alkaline solution with 
a $\mathrm{Na} / \mathrm{Al}$ ratio $=1$ and a given amount of water by the ratio $\mathrm{H}_{2} \mathrm{O} / \mathrm{Na}_{2} \mathrm{O}=11$. Figure 1 shows that $\mathrm{Si} / \mathrm{Al}$ ratios above 1.9 give a lower compressive strength. This reduction may be related to the effect of unreacted materials present, since geopolymers are known to have unreacted amounts of the aluminosilicate source [29], but this depends on the type of aluminosilicate source used. Duxson et al. [30] carried out tests varying the type of alkali used (sodium and potassium hydroxide), each in pure form or as mixtures (Table 1), in addition to the Si / Al molar ratio after 7 and 28 days of aging at ambient conditions to observe the development of the compressive strength and Young's modulus over time. The comparison between the types of alkalis used showed that there is not a great variation in the mechanical properties after seven days. However, after 28 days, the compressive strength of the sample with a mixture of the two types of alkali (where potassium represents at least half of the alkaline solution) showed an increase past the molar ratio of $\mathrm{Si} / \mathrm{Al}=1.90$ compared to the cases in which pure alkalis are used, which show a decrease in compressive strength. This indicates that a mixed use of alkalis would allow higher $\mathrm{Si} / \mathrm{Al}$ molar ratios. It should be noted that at a ratio of 2.15, the geopolymer generated with an alkaline Na50 solution achieved a simple compressive strength of $90 \mathrm{MPa}$, being the highest value compared to the results obtained with pure alkaline solutions of $\mathrm{Na}$ and $\mathrm{K}$ (60 and $50 \mathrm{MPa}$, respectively).

Table 1. Nomenclature for the composition of alkali mixtures in alkaline solution.

\begin{tabular}{ccc}
\hline TAG & Na\% & K\% \\
\hline Na25 & 25 & 75 \\
Na50 & 50 & 50 \\
Na75 & 75 & 25 \\
\hline
\end{tabular}

Wan et al. [31] conducted a study of metakaolin-based geopolymers in a varied range of $\mathrm{Si}$ / Al molar ratios. From the obtained results presented in Figure 1, it was observed that it reached the maximum compressive strength at a $\mathrm{Si} / \mathrm{Al}=1.67$ ratio with a compressive strength of $36.8 \mathrm{MPa}$. The $\mathrm{Na} / \mathrm{Al}$ and $\mathrm{H}_{2} \mathrm{O} / \mathrm{Na}_{2} \mathrm{O}$ ratios are similar to those used by Duxson et al. [27,29] (ratios of 1 and 12, respectively), showing that a continuous increase in the $\mathrm{Si} / \mathrm{Al}$ ratio implies a constant decrease in the compressive strength, where at the $\mathrm{Si} / \mathrm{Al}$ ratios of 3,4 , and 5, a simple compressive strength of approximately 15,11 , and $5 \mathrm{MPa}$ were obtained, respectively.

Perera et al. [32] and Steveson and Sagoe-Crentsil [33] obtained compressive strengths of 61 and $48 \mathrm{MPa}$, respectively, with a Si/Al molar ratio of approximately 2. However, in Steveson's case, the same strength value is reached with two different ratios (1.75 and 1.90), because the ratio of 1.90 was achieved by adding more sodium silicate to the solution compared to the geopolymer that was designed. Although, with a ratio of 1.75 , this result shows that increasing the silicon content in the mixture by means of sodium silicate does not alter the compressive strength.

Rodríguez et al. [34] and Subaer [35] obtained optimal compressive strength with a $\mathrm{Si} / \mathrm{Al}$ ratio of 1.5. Figure 1 shows the compressive strength results obtained by Subaer using a $\mathrm{Na} / \mathrm{Al}$ ratio $=1$. From the study, it was observed that this $\mathrm{Na} / \mathrm{Al}$ ratio allows to increase the $\mathrm{Si} / \mathrm{Al}$ ratio without any loss in compressive strength, as compared to lower $\mathrm{Na} / \mathrm{Al}$ ratios, which greatly decrease their strength with an increase in the $\mathrm{Si} / \mathrm{Al}$ ratio over 1.75. Along with the compressive strength results, Subaer studied the effect of varying the $\mathrm{Na} / \mathrm{Al}$ ratio on the apparent porosity of the geopolymers and compared these results with the compressive strength results. He observed that there is an inversely proportional relationship between the two results, implying that porosity controls compressive strength to some extent, because the higher the porosity, the lower the compressive strength. It should also be noted that the permeability of materials is largely controlled by porosity (Angelone, et al. [36]), indicating that conditions that reduce compressive strength are those that subsequently increase the permeability of the geopolymer. As expected, a decrease in porosity implies a more homogeneous and compact microstructure, which in turn leads to lower permeability and higher compressive strengths [37], as shown by a study by 
Sun et al. [38]. In order to obtain lower porosities in geopolymers, the curing temperature must be increased, as shown in several previous studies [39]. The pore size of alkali activated materials can be affected due to carbonation, where this increases the size of the pores, which in turn leads to losses in strength [40].

In order to obtain higher compressive strengths, several authors have added different aggregates to geopolymeric mixtures [41], such as sand [42,43], granite [44], gravel, sawdust [45], dolomite [46], glass [47-51], recycled materials [52], among others. On the other hand, it has been shown that milling of the blend of raw materials produced hydraulic cements with improved compressive strength when compared with separately milled raw materials that were blended after milling [53]. Similarly, it has been observed that grinding the aluminosilicate source to obtain a finer material also produces improvements in the compressive strength of the geopolymers produced [54-58]. The reactivity of raw materials during alkali activation is an important factor for geopolymer applications. For example, mine tailings have low reactivity, which leads to products with poor mechanical strength [59], incorporating additives like metakaolin or slag can improve the properties of the resultant alkali activated material [59-61].

Zhang et al. [62] conducted a study in which the long-term compressive strength of heat cured fly ash geopolymer concrete was analyzed. Figure 1 shows the compressive strength obtained after 480 days of aging of a fly ash geopolymer concrete activated with a $14 \mathrm{M} \mathrm{NaOH}$ solution at different $\mathrm{Si} / \mathrm{Al}$ ratios. Compressive strength was first observed to increase with the increase in $\mathrm{Si} / \mathrm{Al}$ ratio and with $\mathrm{Si} / \mathrm{Al}$ ratio close to 1.87 tended to show high compressive strength. The compressive strength of fly ash geopolymer concretes prepared with $\mathrm{NaOH}$ solutions of different molarity was also analyzed in this study. To some extent, the influence of $\mathrm{Si} / \mathrm{Al}$ molar ratio on the long-term compressive strength was affected by the concentration of $\mathrm{NaOH}$ solution.

Rodríguez et al. [34] presented a similar phenomenon in its results with respect to Subaer [35], as greater strength was obtained at a molar ratio of $\mathrm{Si} / \mathrm{Al}=1.5$ and from then on, its values of compressive strength decreased (Figure 1). Among the results obtained in this study, it was also found that the increase in the amount of Na caused a decrease in the compressive strength of geopolymer concretes.

Riahi et al. [63] achieved maximum compressive strength at a Si/Al molar ratio of around 1.63 and a $\mathrm{Na} / \mathrm{Al}$ ratio of 1 , showing a bell effect like most of the investigated cases $[27,29,30,34]$, because the compressive strength first increases with the Si/Al ratio and then decreases as the $\mathrm{Si} / \mathrm{Al}$ ratio continues to increase (Figure 1).

Yunsheng et al. [64] achieved a simple compressive strength of $34.9 \mathrm{MPa}$ with a $\mathrm{Si} / \mathrm{Al}$ ratio of 2.75, an $\mathrm{Na} / \mathrm{Al}$ ratio of 1 , and an $\mathrm{H}_{2} \mathrm{O} / \mathrm{Na}_{2} \mathrm{O}$ ratio of 7 . Rowles and O'Connor [65,66] obtained similar results in two studies (Table 2), obtaining a compressive strength of $64 \mathrm{MPa}$ with a $\mathrm{Si} / \mathrm{Al}$ ratio of 2.5 and an $\mathrm{Na} / \mathrm{Al}$ ratio of 1.29.

Table 2. Results of compressive strength at different ratios of $\mathrm{Si} / \mathrm{Al}$ and $\mathrm{Na} / \mathrm{Al}$ [65].

\begin{tabular}{ccccccc}
\hline & \multicolumn{7}{c}{ Simple Compressive Strength [MPa] } \\
\cline { 2 - 7 } Si/Al & $\mathbf{0 . 7 2}$ & $\mathbf{1 . 0 0}$ & $\mathbf{1 . 2 9}$ & $\mathbf{1 . 5 3}$ & $\mathbf{2 . 0 0}$ \\
\cline { 2 - 7 } & $\mathbf{0 . 5 1}$ & 2.2 & 4.4 & - & - & - \\
\hline 1.08 & 0.4 & 6.2 & 23.4 & - & 19.8 & - \\
\hline 1.50 & - & - & 51.3 & 53.1 & - & 11.8 \\
\hline 2.00 & - & - & - & 64.0 & 49 & - \\
\hline 2.50 & - & - & - & - & 2.6 & 19.9 \\
\hline 3.00 & - & - &
\end{tabular}

Zhang et al. [17] conducted a study based on fly ash and copper tailings from a mine in the United States, where he worked with different proportions of these two sources. The work of Zhang et al. showed that as the amount of tailings increased, 
the compressive strength decreased, so the best result was with $25 \%$ tailings and $75 \%$ ashes, which gave a $\mathrm{Si} / \mathrm{Al}$ ratio of 2.38. It should be noted that at the highest value of $\mathrm{Si} / \mathrm{Al}(7.78)$, it subsequently obtained a compressive strength between 1 and $3 \mathrm{MPa}$ when the molar concentration of the alkaline solution was varied. The constant reduction of the compressive strength when increasing the content of tailings in the formation of the geopolymer is because this alone has a very high $\mathrm{Si} / \mathrm{Al}$ ratio. Therefore, increasing the proportion of tailings with respect to fly ash will imply an increase in the $\mathrm{Si} / \mathrm{Al}$ ratio that ends up delivering low values of compressive strength. In addition, the amount of soluble silicon and aluminum that the tailings can contribute to the formation of the geopolymer is low because the tailings are composed mainly of crystalline phases, since they do not undergo a high temperature process in their formation.

Singh et al. [67] conducted a study based on the behavior of red mud based geopolymers cured at room temperature, with the addition of different aluminosilicate sources such as fly ash, slag, and microsilica. The study showed that an increase in the $\mathrm{Si} / \mathrm{Al}$ ratio led to an increase in the compressive strength of the geopolymer concrete (Figure 1), the optimum point being at $\mathrm{Si} / \mathrm{Al}$ ratio $=2\left(\mathrm{SiO}_{2} / \mathrm{Al}_{2} \mathrm{O}_{3}=4\right)$ where a compressive strength of $40 \mathrm{MPa}$ was obtained. Higher amounts of silica led to a loss in compressive strength. This may be due to the small amount of aluminum in relation to the amount of silicon, so that with high silicon contents there would be unreacted silicon and, therefore, not so much geopolymeric gel would be formed [68].

The following is a compilation plot of the compressive strength data as a function of the $\mathrm{Si} / \mathrm{Al}$ ratio collected from the above-mentioned investigations. In general, it can be observed that most of the authors obtained the highest compressive strengths using a Si / $\mathrm{Al}$ ratio between 1.5 and 2. However, it should be noted that the strength obtained depends not only on the $\mathrm{Si}$ /al ratio, but also on many factors such as the type of aluminosilicate source, the type of alkaline activator and its concentration, curing temperature, among others; therefore, the strength obtained cannot be attributed only to the silicon and aluminum content.

Table 3 shows the ratios obtained for the different researchers to achieve the compressive strength using geopolymers. From the studies analyzed, the $\mathrm{Si} / \mathrm{Al}$ ratio varied from 1.5 to 2.75 , being in most cases, values close to 2 where the highest compressive strengths were obtained. The $\mathrm{Na} / \mathrm{Al}$ ratio varied from 0.6 to 1.3 , with the most commonly used ratio being 1.0. The $\mathrm{H}_{2} \mathrm{O} / \mathrm{Na}_{2} \mathrm{O}$ ratio of 11 was the most used by the majority of the authors. It should be noted that the resistance obtained also depends on other variables such as the source of aluminosilicates and the way of preparation of the geopolymeric mixtures.

Duxson et al. [28] studied the microstructure of alkali activated materials to find out how the Si/Al ratio influenced it. It was concluded that the N-A-S-H gel of the geopolymer is what controls the compressive strength of the geopolymer. It was evident that, at low $\mathrm{Si} / \mathrm{Al}$ ratios, the material would appear more porous since there would not be enough $\mathrm{N}-\mathrm{A}-\mathrm{S}-\mathrm{H}$ gel formation to give homogeneity to the geopolymer. As the $\mathrm{Si} / \mathrm{Al}$ ratio is increased, a greater homogeneity of the mixture is observed and, therefore, a reduction in porosity. This shows that the same variables that improve the strength of the geopolymers are the same that allow the material to be less porous and, accordingly, less permeable.

The study shows that there is an abrupt change in the microstructure when the $\mathrm{Si} / \mathrm{Al}$ ratio increases from 1.45 to 1.60 , qualitatively showing that the porosity is significantly reduced to accommodate a more homogeneous material. 
Table 3. Summary of bibliographic research on the influence of ratios on mechanical strength (CT = Copper tailings).

\begin{tabular}{|c|c|c|c|c|c|c|}
\hline Source & $\begin{array}{c}\text { Ratio Si/Al } \\
\text { Optimal }\end{array}$ & Na/Al Ratio & $\mathrm{H}_{2} \mathrm{O} / \mathrm{Na}_{2} \mathrm{O}$ Ratio & $\begin{array}{c}\text { Mixing and Setting } \\
\text { Conditions }\end{array}$ & $\begin{array}{c}\text { UCS Strength } \\
{[\mathrm{MPa}]}\end{array}$ & Reference \\
\hline Metakaolin & 1.9 & 1 & $11\left(\mathrm{H}_{2} \mathrm{O} / \mathrm{Na}_{2} \mathrm{O}\right)$ & $\begin{array}{l}10 \text { min of mechanical mixing. } \\
\text { Vibration for air removal. } \\
\text { Cured at } 25-30^{\circ} \mathrm{C} \text { for } 24 \mathrm{~h} .\end{array}$ & 81.6 & Lahoti et al. [25] \\
\hline Metakaolin & 1.9 & 1 & $11\left(\mathrm{H}_{2} \mathrm{O} / \mathrm{Na}_{2} \mathrm{O}\right)$ & $\begin{array}{l}15 \mathrm{~min} \text { of mechanical mixing. } \\
15 \mathrm{~min} \text { of vibration. Cured at } \\
40^{\circ} \mathrm{C} \text { for } 20 \mathrm{~h} .\end{array}$ & 75 & Duxson et al. [28] \\
\hline Metakaolin & 1.9 & $0.75(\mathrm{~K} / \mathrm{Al}=0.25)$ & $11\left(\mathrm{H}_{2} \mathrm{O} / \mathrm{Na}_{2} \mathrm{O}\right)$ & $\begin{array}{l}15 \mathrm{~min} \text { of mechanical mixing. } \\
15 \mathrm{~min} \text { of vibration. Cured at } \\
40{ }^{\circ} \mathrm{C} \text { for } 20 \mathrm{~h} \text {. } 28 \text { days of rest } \\
\text { at ambient conditions. }\end{array}$ & $\sim 95$ & Duxson et al. [30] \\
\hline Metakaolin & 2 & 1 & $\begin{array}{c}12\left(\mathrm{H}_{2} \mathrm{O} / \mathrm{Na}_{2} \mathrm{O}\right) \\
-1.12 \mathrm{~g} / \mathrm{mL} \\
\text { (solid/liquid ratio) }\end{array}$ & $\begin{array}{l}5 \mathrm{~min} \text { of mechanical mixing. } \\
3 \mathrm{~min} \text { vibration. First cures at } \\
60^{\circ} \mathrm{C} \text { for } 6 \mathrm{~h} \text { and then at } \\
\text { room temperature for } 7 \text { days. }\end{array}$ & 36.8 & Wan et al. [31] \\
\hline Metakaolin & 2 & 1 & $7.2\left(\mathrm{H}_{2} \mathrm{O} / \mathrm{Na}_{2} \mathrm{O}\right)$ & $\begin{array}{l}\text { Mixed for } 5 \mathrm{~min} \text {. Vibration } \\
\text { for } 5 \mathrm{~min} \text {. Room temperature } \\
\text { cure for } 24 \mathrm{~h} \text {, then cure at } \\
40^{\circ} \mathrm{C} \text { for } 24 \mathrm{~h} \text {. }\end{array}$ & 61 & Perera et al. [32] \\
\hline Metakaolin & $1.75-1.9$ & 1.2 & $12\left(\mathrm{H}_{2} \mathrm{O} / \mathrm{Na}_{2} \mathrm{O}\right)$ & Cured at $85^{\circ} \mathrm{C}$ for $2 \mathrm{~h}$. & 48 & Steveson et al. [33] \\
\hline Metakaolin & 1.5 & 0.6 & $10\left(\mathrm{H}_{2} \mathrm{O} / \mathrm{Na}_{2} \mathrm{O}\right)$ & $\begin{array}{l}\text { Mixed for 5-10 min. } \\
\text { Vibration for } 2 \min \text {. Cured at } \\
70^{\circ} \mathrm{C} \text { for } 2 \mathrm{~h} .\end{array}$ & 86 & Subaer [35] \\
\hline Fly ash & 1.87 & 1.2 & $11\left(\mathrm{H}_{2} \mathrm{O} / \mathrm{Na}_{2} \mathrm{O}\right)$ & $\begin{array}{l}\text { Mixed for } 8 \text { min. Vibration } \\
\text { for air removal. Cured at } \\
80^{\circ} \mathrm{C} \text { for } 24 \mathrm{~h} \text {. }\end{array}$ & 88 & Zhang et al. [62] \\
\hline Metakaolin & 1.5 & 0.75 & $12\left(\mathrm{H}_{2} \mathrm{O} / \mathrm{Na}_{2} \mathrm{O}\right)$ & $\begin{array}{l}\text { Mixed for } 12 \text { min. Vibration } \\
\text { for } 5 \text { min. Rest in airtight } \\
\text { container for } 7 \text { days with } \\
\text { relative humidity of } 90 \% .\end{array}$ & 35 & Rodríguez et al. [34] \\
\hline Metakaolin & 1.63 & 0.9 & $11.25\left(\mathrm{H}_{2} \mathrm{O} / \mathrm{Na}_{2} \mathrm{O}\right)$ & $\begin{array}{l}\text { Mixed for } 10 \mathrm{~min} \text {. Vibration } \\
\text { for } 2 \mathrm{~min} \text {. Cured at } 50^{\circ} \mathrm{C} \text { and } \\
90 \% \text { relative humidity for } \\
24 \mathrm{~h} \text {. }\end{array}$ & $\sim 60$ & Riahi et al. [63] \\
\hline Metakaolin & 2.75 & 1 & $7\left(\mathrm{H}_{2} \mathrm{O} / \mathrm{Na}_{2} \mathrm{O}\right)$ & $\begin{array}{l}\text { Mixed for } 3 \mathrm{~min} \text {. Vibration } \\
\text { for } 2 \mathrm{~min} \text {. Cured at } 20^{\circ} \mathrm{C} \text { and } \\
95 \% \text { relative humidity for } \\
28 \text { days. }\end{array}$ & 34.9 & Yunsheng et al. [64] \\
\hline Metakaolin & 2.5 & 1.3 & $\begin{array}{l}15 \text { moles of water } \\
\text { per } 1 \text { of metakaolin }\end{array}$ & Cured at $75^{\circ} \mathrm{C}$ for $24 \mathrm{~h}$. & 64 & Rowles et al. [65] \\
\hline Metakaolin & 2.5 & 1.25 & $\begin{array}{l}111 \mathrm{~g} \text { of } \mathrm{H}_{2} \mathrm{O} \text { per } \\
100 \mathrm{~g} \text { of metakaolin }\end{array}$ & Cured at $75^{\circ} \mathrm{C}$ for $24 \mathrm{~h}$. & 65 & Rowles et al. [66] \\
\hline $\begin{array}{l}\text { Copper tailings and } \\
\text { fly ash }\end{array}$ & $2.38(25 \% \mathrm{CT})$ & $0.94(25 \% \mathrm{CT})$ & $27 \%$ (water/solids) & $\begin{array}{l}\text { Mixed for } 10 \text { min. Vibration } \\
\text { for } 2 \text { min. } 7 \text { days of curing at } \\
60^{\circ} \mathrm{C} \text {. }\end{array}$ & $14(25 \%$ CT $)$ & Zhang et al. [17] \\
\hline $\begin{array}{l}\text { Red mud and fly } \\
\text { ash }\end{array}$ & 2.45 & 0.8 & $30 \%$ (water/solids) & $\begin{array}{l}\text { Mixed for } 5 \mathrm{~min} \text {. Cured at } \\
60^{\circ} \mathrm{C} \text { for } 24 \mathrm{~h} .\end{array}$ & 38 & Singh et al. [67] \\
\hline Gold mine tailings & 10.7 & 0.04 & $26 \%$ (water/solids) & $\begin{array}{l}\text { Mixed for } 15 \text { min and } \\
\text { molded. Cured at } 80^{\circ} \mathrm{C} \text { for } \\
5 \text { days. }\end{array}$ & 10 & Falayi 2019 [69] \\
\hline $\begin{array}{l}\text { Garnet tailings and } \\
\text { metakaolin }\end{array}$ & 6.6 & 0.04 & - & $\begin{array}{l}\text { Mixed for } 10 \text { min. Vibration } \\
\text { for } 5 \text { min. Cures at } 40{ }^{\circ} \mathrm{C} \text { for } \\
\text { 3 days. }\end{array}$ & 46 & Wang et al. [70] \\
\hline $\begin{array}{c}\text { Iron ore mine } \\
\text { tailings }\end{array}$ & 5.98 & - & - & $\begin{array}{l}\text { Mixed for } 10 \mathrm{~min} \text {. Cured at } \\
80^{\circ} \mathrm{C} \text { for } 3 \text { days. }\end{array}$ & 34 & Kuranchie et al. [71] \\
\hline $\begin{array}{l}\text { Coal gangue, blast } \\
\text { furnace slag and } \\
\text { lead-zinc tailings }\end{array}$ & 2.0 & - & $27 \%$ (water/solids) & $\begin{array}{l}\text { Mixed and vibrated for } 5 \mathrm{~min} \text {. } \\
\text { Cured at } 30^{\circ} \mathrm{C} \text {. }\end{array}$ & 91.13 & Zhao et al. [72] \\
\hline
\end{tabular}

It was observed that at $\mathrm{Si} / \mathrm{Al}$ ratios of 1:1, a small amount of N-A-S-H gel is formed, and a certain amount of zeolite nuclei is present. However, most of these are not dispersed in the binder, causing the formation of macropores. At $\mathrm{Si} / \mathrm{Al}$ ratios of 2:1, a homogeneous geopolymer is formed due to the large formation of N-A-S-H gel dispersed in the matrix. At $\mathrm{Si} / \mathrm{Al}$ ratios of 3:1, derivatives of soluble silicates (e.g., silicic acid) are observed in the geopolymer, allowing the N-A-S-H gel to lose its predominance. At 4:1 ratio, the N-A-S-H gel is not observed, and many micropores are formed, thus generating a large network of interconnected pores.

A study by Lahoti et al. [73] showed that by varying the $\mathrm{Si} / \mathrm{Al}$ ratio of metakaolinbased geopolymers, different properties of compressive strength and volumetric stability 
are obtained after being subjected to high temperatures. From the study it was obtained that with a $\mathrm{Si} / \mathrm{Al}$ ratio = 2, the highest strength endurance and the lowest volume reduction are obtained. This was mainly due to the fact that with this composition, the geopolymer matrix is denser, which resulted in higher volumetric stability.

\subsection{Curing Temperature and Time}

Curing conditions largely control the formation of alkali activated materials, as elevated temperatures increase the rate of chemical reactions [74] and dissolution of reactive species $[75,76]$, therein increasing the interaction between the aluminosilicate source and the alkaline solution at the time of the geopolymer synthesis [77]. Previous research has shown that both curing time and curing temperature significantly influence the compressive strength of geopolymer concrete [78-80].

Tian et al. [81] analyzed the effect of curing temperature on the microstructure of a geopolymer based on Chinese copper tailings and fly ash. From the results, it was obtained that with a curing time of $48 \mathrm{~h}$, the compressive strength after 3, 7, and 28 days of aging in ambient conditions does not vary much, with the optimum temperature for the three cases being $80^{\circ} \mathrm{C}$, which demonstrates the rapid geopolymerization reaction. There is a change in the compressive strength of $25^{\circ} \mathrm{C}$ to $80^{\circ} \mathrm{C}$ of around $25 \mathrm{MPa}$, and when going from $80^{\circ} \mathrm{C}$ to $120^{\circ} \mathrm{C}$, the compressive strength decreases by around $12 \mathrm{MPa}$ (Figure 2).

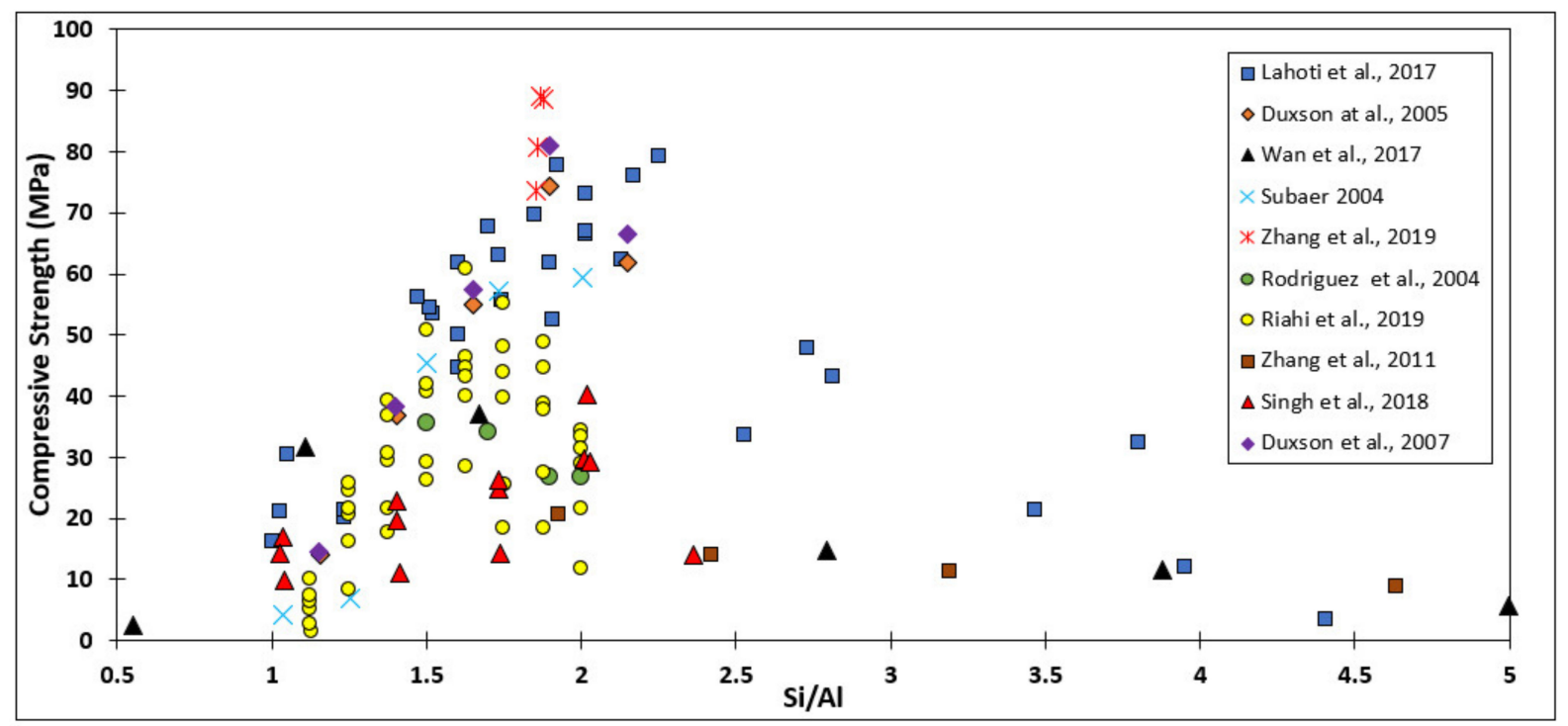

Figure 2. Graph compiling compressive strength vs. Si / Al ratio data obtained from previous investigations $[17,25,28,30,31$, $34,35,62,63,67]$.

Previous studies show that the conditions in which alkaline activated materials are cured must be controlled, due to the possible carbonation that can occur due to the contact between the alkaline geopolymer mixture and the $\mathrm{CO}_{2}$ coming from the air [82-84]. The mechanism of carbonation in alkali-activated geopolymers is obviously different from that which takes place in Portland cement [85]. In Portland cement pastes, atmospheric $\mathrm{CO}_{2}$ dissolves in the pore solution and reacts rapidly with portlandite to form $\mathrm{CaCO}_{3}$, and then with Calcium-Silicate-Hydrate gel (C-S-H) to form $\mathrm{CaCO}_{3}$ and silica gel [86]. In contrast, the carbonation of alkali-activated pastes occurs directly in the Calcium-AluminosilicateHydrate gel (C-A-S-H) because of the lack of portlandite, leaving an alumina-containing remnant siliceous gel in addition to $\mathrm{CaCO}_{3}[87,88]$.

A relative humidity of $95 \%$ in the curing chambers can inhibit the initial carbonation in geopolymers [89]. Other studies show that the optimum humidity in the curing chamber is $70 \%$, which leads to improvements in the compressive strength of geopolymers [90].

Kong et al. [91] conducted an investigation to observe the behavior of alkali activated materials when subjected to an environment of high temperatures after their formation 
(650-800 ${ }^{\circ} \mathrm{C}$ ) and to compare their behavior with alkali activated materials without exposing them to high temperatures. In the mixture without exposure to high temperatures, the behavior was similar to that of Tian et al. [81], where the optimum curing temperature to achieve high compressive strength was at $80{ }^{\circ} \mathrm{C}$ for a period of $24 \mathrm{~h}$ and thereafter the value of compressive strength decreased with increasing curing temperature. Kong et al. relates this phenomenon to the evaporation of water in the pores of the geopolymer at high temperatures. However, in mixtures exposed to high temperatures, this effect is not evident, since the moisture in the system is completely dissipated when at temperatures above $650^{\circ} \mathrm{C}$, so the strength inhibiting effect is lost by evaporation of the water.

Hardjito and Rangan [92] studied the behavior of fly ash-based geopolymers, where they observed the influence of using different temperatures and curing times. Two mixtures were analyzed in the study, which are distinguished by their $\mathrm{NaOH}$ concentration ("Mixture 2": $8 \mathrm{M}$, and "Mixture 4": $14 \mathrm{M}$ ). Both mixtures were subjected to different curing temperatures, the first for $24 \mathrm{~h}$ and the second for $6 \mathrm{~h}$. It was observed that the three experiments achieved their optimum point of compressive strength at $90{ }^{\circ} \mathrm{C}$ (similar to that presented by Tian et al. [81] and Kong et al. [91]), indeed, the mixture having better performance with $14 \mathrm{M} \mathrm{NaOH}$. When comparing the results of "Mixture 2" at different times, it was concluded that raising the curing time from $6 \mathrm{~h}$ to $24 \mathrm{~h}$ for the same $\mathrm{NaOH}$ concentration achieved an increase of around $25 \mathrm{MPa}$.

Ahmari et al. [93] studied the relationship between curing temperature and alkalinity of a copper tailings geopolymer concrete based on the concentration of $\mathrm{NaOH}$ used. It was observed that at low alkalinity (5-10 M NaOH), the influence of the curing temperature is not so significant, whereas at a concentration of $15 \mathrm{M} \mathrm{NaOH}$ a drastic increase in strength was observed at a temperature of $90^{\circ} \mathrm{C}$. The results presented by Hardjito [92] presents a similar phenomenon, where the mixture with $15 \mathrm{M} \mathrm{NaOH}$ gave better results at a similar curing temperature. Therefore, it should be acknowledged that in a system with high alkalinity, the curing temperature is more influential and is optimal at a temperature between $80-90{ }^{\circ} \mathrm{C}[78,88,89]$. Additionally, Ahmari et al. [93] observed the Si and $\mathrm{Al}$ concentration in the geopolymer at different temperatures and $\mathrm{NaOH}$ concentrations (Table 4) where an increase in the concentrations of both elements was observed with increasing curing temperature and alkalinity. This allows a greater dissolution of $\mathrm{Si}$ and $\mathrm{Al}$ from the aluminosilicate source, and since there is an increase in the presence of these elements in the geopolymer with increasing $\mathrm{NaOH}$ concentration, this implies that there is a greater contribution of these species to the formation of the NASH gel.

Table 4. Si and $\mathrm{Al}$ concentrations in the geopolymer at different curing temperatures and $\mathrm{NaOH}$ concentrations [93].

\begin{tabular}{ccccccc}
\hline \multirow{2}{*}{ Composition } & \multicolumn{7}{c}{ Temperature $\left({ }^{\circ} \mathbf{C}\right)$} \\
\cline { 2 - 7 } & & $\mathbf{6 0}$ & & $\mathbf{9 0}$ & \\
\hline $\mathrm{NaOH}(\mathrm{M})$ & 5 & 10 & 15 & 10 & 15 \\
\hline $\mathrm{Si}(\mathrm{ppm})$ & 71 & 171 & 233 & 1846 & 3970 & 4570 \\
\hline $\mathrm{Al}(\mathrm{ppm})$ & 28 & 76 & 121 & 299 & 319 & 550 \\
\hline $\mathrm{Si} / \mathrm{Al}$ & 2.44 & 2.16 & 1.85 & 5.93 & 11.9 & 7.98 \\
\hline
\end{tabular}

Manjarrez et al. [94] conducted a study in which the effect of the curing temperature of tailings and low-calcium slag based geopolymers activated with a mixture of sodium silicate and sodium hydroxide $(\mathrm{SS} / \mathrm{NaOH}=1)$ was analyzed. The research shows that for a geopolymer made of 50\% slag and 50\% tailings, the temperature has a significant effect on the mechanical properties of geopolymer. It was shown that higher curing temperatures produce geopolymers with higher compressive strength. Due to the temperature range studied, no optimum curing temperature point was found, so it follows that 
higher strengths would have been obtained if higher curing temperatures (e.g., $90^{\circ} \mathrm{C}$ ) had been used.

In general, it can be observed that using moderately high curing temperatures (between 80 and $90{ }^{\circ} \mathrm{C}$ ) induces an improvement in the compressive strength of alkaline active geopolymers [95], because a higher temperature causes a higher interaction between the components of the mixture, higher reaction kinetics, as well as acceleration in the polycondensation process and formation of a hardened structure due to an increase in the dissolution of amorphous phases [96]. This can be seen in the compilation graph (Figure 2), which shows the compressive strength obtained at different curing temperatures by the different authors in the above-mentioned investigations. Although an optimum temperature between 80 and $90{ }^{\circ} \mathrm{C}$ was found in all the cases analyzed, the compressive strength obtained from one study to another varied greatly. This is due to the fact that the strength generated by the geopolymers does not depend simply on the curing temperature, but on more important variables such as the composition and type of aluminosilicate source.

Sun and Vollpracht [97] investigated the performance of fly ash and metakaolin-based geopolymer concretes over a one-year period, highlighting among the variables, studying the temperature and the curing time with which the geopolymer was formed and also the aging time under ambient conditions. Figure 3 shows the evolution over time of a fly ash geopolymer, where there is a significant increase during the first 100 days of aging of the geopolymer. After 100 days of aging at ambient conditions, the geopolymer does not present drastic changes in its strength. It was observed that the compressive strength does not undergo a decrease throughout the aging of the geopolymer for any of the cases.

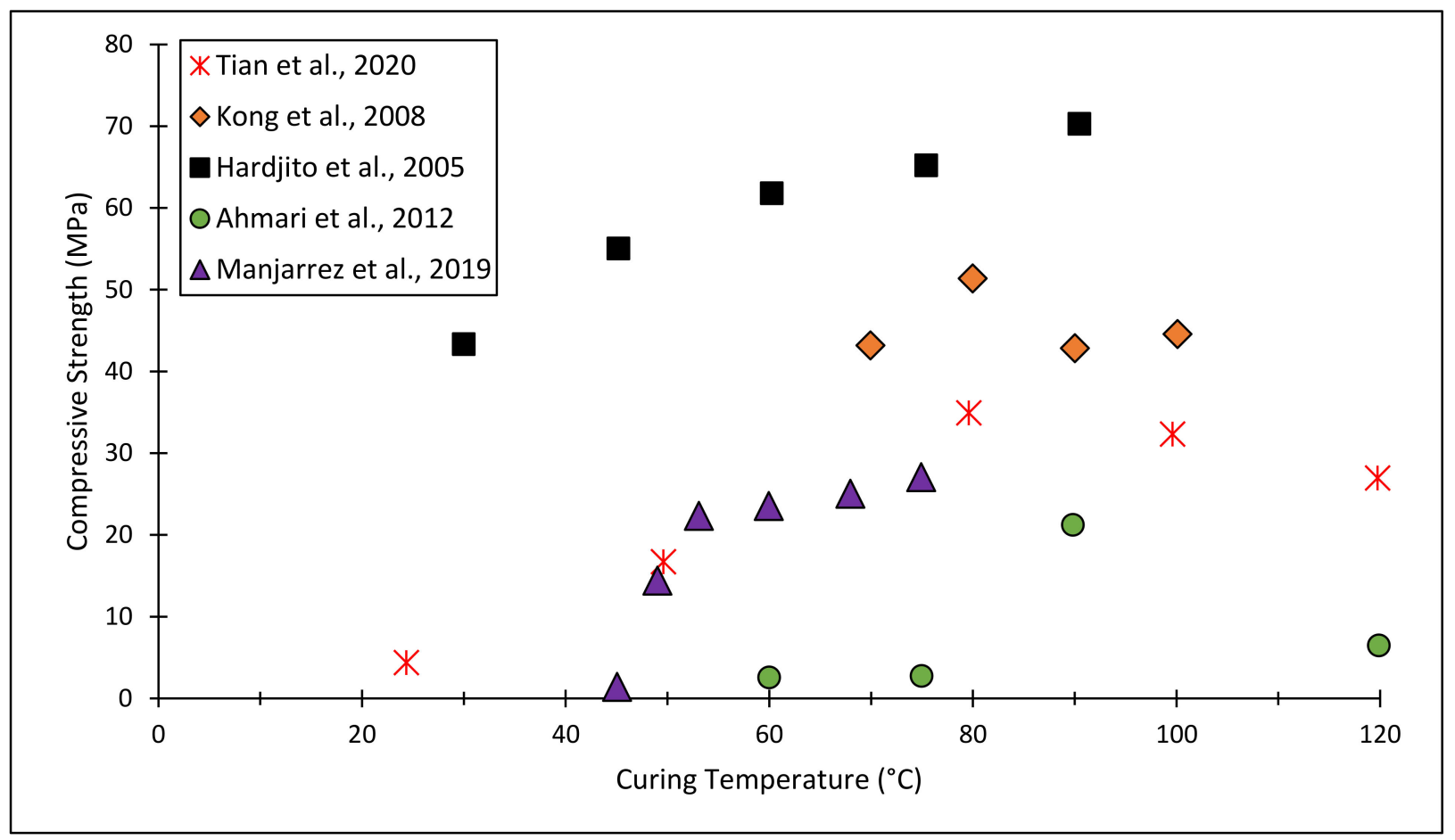

Figure 3. Graph compiling compressive strength vs. curing temperature data obtained from previous investigations [81,91-94].

Hardjito et al. [92] also analyzed the effect of curing time on low-calcium fly ash-based geopolymers cured at $60^{\circ} \mathrm{C}$ (Figure 3). It accordingly demonstrates that the compressive strength subsequently increases with the curing time, also to be noted, increasing drastically within the first $24 \mathrm{~h}$, then decreased to a slower rate, which may indicate that the dissolution of much of the aluminosilicate source occurs within the first hours of curing.

Villa et al. [98] conducted a study analyzing the behavior of alkaline-activated zeolitebased geopolymers, where he found that the highest compressive strengths were obtained 
at a curing temperature of $40^{\circ} \mathrm{C}$. It is also observed that lower curing temperatures required longer curing times [99].

Okoye et al. [100] investigated the mechanical properties of alkali activated fly ash/kaolin based geopolymer concrete. Among the results of his research, he found that the highest compressive strengths were obtained with a mixture of $50 \%$ fly ash and $50 \%$ Kaolin. On the other hand, he analyzed the effect of curing time on the compressive strength of these geopolymers using different alkaline alkali activators ( $\mathrm{KOH}$ and $\mathrm{NaOH}$ ); from this it was obtained that for both cases, the compressive strength increased with curing time, the maximum being at 28 days of curing. In turn, the geopolymers activated with $\mathrm{NaOH}$ obtained higher strengths than those activated with $\mathrm{KOH}$.

Samantasinghar and Prasad [101] conducted a study in which they analyzed the behavior of geopolymer concretes made with granulated blast furnace slag and fly ash in variable contents, activated with an $8 \mathrm{M}$ sodium hydroxide solution. In this study, a total of six different fly ash-slag mixtures were prepared by varying fly ash and slag percentages at intervals of $20 \%$. The investigation shows that an increase in slag content in the mixture results in an increase of compressive strength. The high reactivity of soluble aluminosilicate material in the alkaline media causes an increase of the silicon and aluminum content in the aqueous phase. These alumino-silicates make the polycondensation process more efficient, which helps in the formation of a good quality matrix. Thus, a stronger material possessing high compressive strength is obtained. Granulated blast furnace slag contains mostly reactive alumino-silicates and the leaching of ions from this slag is much higher under a given alkaline condition than from fly ash [101].

In this study, it was observed that the curing period plays a critical role in the development of compressive strength. Further, at a specified curing period, the slag rich specimen registers higher strength values than fly ash specimen. No such significant strength gain is observed with increasing cure duration for mixtures with higher slag content. The mix S100 gained about $70 \%$ of its 90 days strength at the age of seven days (Figure 3) whereas for $\mathrm{S} 0$, it is $11 \%$. The rate of reaction for fly ash is relatively slow compared to slag. The presence of calcium-bearing compounds in GGBS promotes quick setting, which gives early strength [101].

In recent years, several alternatives have been studied to replace the classic cement as a building material. Geopolymers, in the family of inorganic aluminosilicate binder, has received extensive interests because of high temperature resistance [70,102-105], low permeability [106-110], strong bonding and good durability [51,111-113], excellent chemical corrosion resistance [114-118], and environmental friendliness [119,120], etc. Some of the uses that have been investigated for alkaline activated materials are: as sustainable construction material [121-126], mine backfilling [127,128], porous spheres as novel $\mathrm{pH}$ buffers [129,130], bricks [71,112,131,132], porous thermal insulation material [133], as road material [134], for immobilization of toxic metals and nuclear waste management [135-140], coatings for concrete [141], as waterproof surface [142], etc.

Comparative studies regarding the production price of geopolymers relative to the production price of OPC indicate that geopolymers are likely to be at a price performance disadvantage under current pricing structures. Some studies show that geopolymers range from $7 \%$ below the OPC production price to 39\% higher, depending on the composition of the geopolymer $[143,144]$. This is why alternatives should be sought to lower the production costs of geopolymers, such as the use of waste from other industries as sources of aluminosilicates and activators.

On the other hand, it is possible to obtain hardened alkaline activated geopolymers without the need to be heated in a furnace [145], i.e., they harden at ambient temperature [57,146-149]. Some studies try to give uses to geopolymers cured at ambient temperature, as in the case of three-dimensional concrete printing [150-152].

A study by Somna et al. [54] shows the compressive strength obtained from an alkali activated material based on $\mathrm{NaOH}$-activated grounded fly ash after 60 days of curing at room temperature. From the results presented in Figure 3, it can be observed 
that as in heat-cured geopolymers, time plays an important role in the development of compressive strength of geopolymers cured at ambient temperature. Geopolymers with higher concentrations of the alkaline activator developed higher strengths and in a shorter time, with the optimum concentration found at $14 \mathrm{M}$.

Although some studies show that hot cured geopolymers have better compressive strengths than geopolymers cured at ambient temperature [153-155], the latter can also exhibit high compressive strengths [156,157], as shown in a study by Khan et al. [158], where a compressive strength of $108 \mathrm{MPa}$ was obtained with an alkali activated material based on fly ash and slag.

Some authors have studied the effect of using seawater for the manufacture of alkaline activated geopolymers [159], where it has been observed that the use of salt water tends to improve the compressive strength of geopolymers cured at room temperature [160].

Ding et al. [161] carried out a study analyzing the properties of ambient temperature cured geopolymers based on slag and fly ash. From the results of the study, it was found that an increase in the amount of slag led to better compressive strengths. The highest strength gain was obtained in the first 28 days of curing ( $64 \mathrm{MPa}$ ), since at 90 days of curing a strength of $79 \mathrm{MPa}$ was obtained, increasing only $15 \mathrm{MPa}$ (Figure 3).

Previous research has shown that the hardening process (at room temperature) can be accelerated by blending FA with calcium rich source materials like granulated blast furnace slag [162].

In general, it can be observed that longer curing times produce higher compressive strengths in the geopolymers, regardless of the source of aluminosilicates (Figure 3). Further increasing the curing time did not produce a decrease in compressive strength for any of the observed cases. Although the compressive strength continues to increase with curing time, the majority of this strength was generated in the first 28 days of curing for most of the cases, with curing after this time not being as relevant in the increase of compressive strength. It should be made clear that the strength gain with curing time also depends on other factors, such as geopolymer composition and alkali activator concentration. It is also noted that the aging time at ambient temperature, after the curing time, also produces improvements in the compressive strength of the geopolymers. As in the previous graph, the huge variation observed in the compressive strength of geopolymers is mainly due to the type of aluminosilicate source used.

Table 5 shows the optimal conditions regarding temperature and curing time, together with the aging of the geopolymers prior to the tests to achieve the best compressive strength by various researchers.

Table 5. BiblioDiagram compilation of optimal curing conditions based on different authors.

\begin{tabular}{|c|c|c|c|c|c|c|c|}
\hline Source & $\begin{array}{c}\text { Curing } \\
\text { Temperature }\left({ }^{\circ} \mathrm{C}\right)\end{array}$ & Curing Time (1) & Aging Time (2) & Setting Time $(1+2)$ & UCS (MPa) & $\mathrm{Si} / \mathrm{Al}$ & Reference \\
\hline $\begin{array}{l}\text { Tailings and } \\
\text { fly ash }\end{array}$ & 80 & $48 \mathrm{~h}$ & 28 days & 30 days & 36 & 2.84 & Tian et al. [81] \\
\hline Metakaolin & 80 & $24 \mathrm{~h}$ & 3 days & 4 days & 52 & 1.54 & Ahmari et al. [93] \\
\hline Fly ash & 90 & $24 \mathrm{~h}$ & 7 days & 8 days & 70 & 1.71 & $\begin{array}{c}\text { Hardjito and Rangan } \\
\text { [92] }\end{array}$ \\
\hline Tailings & 90 & 7 days & $6 \mathrm{~h}$ & $174 \mathrm{~h}$ & 23 & 7.78 & Kong et al. [91] \\
\hline $\begin{array}{c}\text { Fly } \\
\text { ash/Metakaolin }\end{array}$ & 20 & - & 350 days & 350 days & $70 / 73$ & $2.93 / 1.81$ & $\begin{array}{l}\text { Sun and Vollpracht } \\
{[97]}\end{array}$ \\
\hline $\begin{array}{c}\text { Fly } \\
\text { ash/kaolin }\end{array}$ & 100 & $72 \mathrm{~h}$ & 28 days & 31 days & 33 & 1.47 & Okoye et al. [100]. \\
\hline $\begin{array}{c}\text { Blast } \\
\text { furnace } \\
\text { slag/Fly ash }\end{array}$ & 20 & - & 90 days & 90 days & 31 & 1.84 & $\begin{array}{l}\text { Samantasinghar and } \\
\text { Prasad [101]. }\end{array}$ \\
\hline $\begin{array}{l}\text { Tailings and } \\
\text { copper slag }\end{array}$ & $>75$ & 7 days & 1 days & 8 days & 25 & 4.94 & Manjarrez et al. [94] \\
\hline
\end{tabular}


Compressive strength changes affected by curing conditions are also related to the microstructure of the geopolymer. Tian et al. [81] concluded in their results, the different ways in which its microstructure is affected:

- At temperatures of $20^{\circ} \mathrm{C}$, cracks were observed in the geopolymer in addition to the appearance of silicon and aluminum without dispersal in the matrix. This is probably due to a poor dissolution of the aluminosilicates, which does not allow a formation of the NASH gel. At temperatures of $80^{\circ} \mathrm{C}$, homogeneity was observed in the structure of the geopolymer, indicating that silicon and aluminum are dispersed in the matrix. At temperatures of $120^{\circ} \mathrm{C}$, the distribution of silicon and aluminum continued to be observed; however, cracks reappeared and suggests the product of a decrease in the formation of the N-A-S-H gel.

- Through X-ray diffraction, they observed that there is a dissolution of the crystalline phases up to $80^{\circ} \mathrm{C}$, and it subsequently increases again when exceeding $100^{\circ} \mathrm{C}$. This would indicate that at moderately high temperatures, it is possible to provide silicon and alumina to promote gel formation. This may be due to the materials used as the source of aluminosilicates, the alkaline conditions, and the subsequent cure time.

- At temperatures above $100{ }^{\circ} \mathrm{C}$, efflorescence is observed, where it is seen that its highest phase is $\mathrm{Na}_{2} \mathrm{CO}_{3} \cdot 7 \mathrm{H}_{2} \mathrm{O}$. Tian et al. indicates that this may be due to the fact that the alkaline activator $(\mathrm{NaOH})$ did not have time to react completely and was exposed to the evaporated water when it was above $100{ }^{\circ} \mathrm{C}$ (consider that for the formation of the geopolymer, it was mixed for $13 \mathrm{~min}$, then $6 \mathrm{~h}$ of curing at $100^{\circ} \mathrm{C}$ and later it was left to age at ambient conditions for different periods ( 3,7 or 28 days) prior to the tests carried out on the geopolymer). Moisture and carbon dioxide from the environment are absorbed and forms $\mathrm{Na}_{2} \mathrm{CO}_{3} \cdot 7 \mathrm{H}_{2} \mathrm{O}$, which decreases the alkalinity of the medium, and, therefore, the dissolution of aluminosilicates is reduced.

\subsection{Alkaline Activator}

As mentioned above, in addition to the aluminosilicate source, an alkaline activator is needed for the geopolymerization process to occur. The commonly used alkaline activators in the geopolymerization process are sodium hydroxide $(\mathrm{NaOH})$, sodium silicate $\left(\mathrm{Na}_{2} \mathrm{SiO}_{3}\right)$, potassium hydroxide $(\mathrm{KOH})$, and potassium silicate $\left(\mathrm{K}_{2} \mathrm{SiO}_{3}\right)[163,164]$.

The type of alkali cation is also important. It was shown that geopolymers based on a mixture of potassium silicate and $\mathrm{KOH}$ exhibit higher mechanical properties than those based on sodium silicate and $\mathrm{NaOH}$ or potassium silicate/ $\mathrm{NaOH}$ mixtures $[165,166]$. The type and concentration of alkali solution affect the dissolution of the aluminosilicate source [167].

Most studies supported that the presence of alkali silicate solution in alkali reactant solution is essential and leads to better microstructure and strength properties [168]. In the reaction process, alkali silicates are combined with hydroxides to achieve better dissolution of the solid precursor and higher reaction rates [169].

The concentration of the activator has a significant effect on the compressive strengths of the geopolymers $[170,171]$. The ideal concentration of the activator increases the strength of the geopolymer. Moreover, an increase in the concentration of the alkaline activator leads to an increase in the $\mathrm{pH}$ of the activating solution. Different authors recommend working at $\mathrm{pH}$ values between 13 and 14 for a correct dissolution of aluminosilicates. This is corroborated by previous studies showing that higher value of hydrogen potential $(\mathrm{pH})$ exhibits higher compressive strength in geopolymer concrete [172]. On the other hand, it has been shown that cement mortars with smaller particle sizes obtain higher $\mathrm{pH}$ values than those containing larger particle sizes [173]. Similarly, an aluminosilicate source with larger particle size tends to react less with the activating solution, due to the smaller exposed area [174].

The release rate of silicate and aluminate species from source materials is critical in controlling the synthesis process of geopolymers and the development of binding gel [175]. 
A high initial dissolution rate of silicate and alumina is known to accelerate the conversion of aluminosilicate materials to geopolymers [176].

It has also been observed that geopolymer mortar samples manufactured with higher alkali content perform better against attack by corrosive chemicals than those manufactured with lower alkali content [177].

Abdullah et al. [178] conducted a study in which they analyzed the effect of varying the amount of alkaline activator, as well as the effect of varying the ratio of sodium silicate to sodium hydroxide in fly ash-based geopolymers. The study did not show clear trends, but a maximum compressive strength of $70 \mathrm{MPa}$ was obtained using a fly ash/alkaline activator ratio of 2.0 and a sodium silicate $/ \mathrm{NaOH}$ ratio of 2.5 , similar to that obtained in other studies [179]. In general, the compressive strength increases with the amount of fly ash and alkaline activator concentration; this is due to the increase in sodium content, which is required for the geopolymerization reaction. It is observed that at a sodium silicate $/ \mathrm{NaOH}$ ratio of 3 , the compressive strength decreases, due to the excess of $\mathrm{OH}^{-}$in the mixtures, in addition to the excess of sodium that can cause the formation of calcium carbonate when it comes in contact with the $\mathrm{CO}_{2}$ in the air.

In the study carried out by Manjarrez et al. [94], where the effect of adding low-calcium slag to copper tailings-based geopolymers, in addition to varying the sodium silicate (SS) $/ \mathrm{NaOH}$ ratio was analyzed. It was obtained that the optimum ratio of $\mathrm{SS} / \mathrm{NaOH}$ was 1.0 since it obtained the highest compressive strength with all slag contents. High ratio of alkali activator/fly ash and $\mathrm{SS} / \mathrm{NaOH}$ (or $\mathrm{KOH}$ ) does not necessarily lead to high compressive strength [180]. It was also observed that at higher slag contents, the composition of the alkaline activator plays a more important role, since it produces greater increases in the compressive strength compared to when the slag is not added. On the other hand, it is clearly observed that an increase in the slag content produces an increase in the compressive strength of the geopolymer, this variable having a greater effect than the variation in the composition of the alkaline activator. The authors comment that the higher the slag content the better the fluidity of the slurry, so that a smaller amount of water is required to form the mixture; this is similar to what has been observed by other authors [181,182]. Using less water is favorable because it implies using a lower amount of alkaline reagents to reach the desired concentration, which in turn generates a benefit in the production cost of the geopolymers. The increase in compressive strength with increasing slag content is attributed to the physical and chemical properties of the slag, since the slag powder is finer than the copper tailings, so the particles have a larger surface area, which favors chemical reactions with the alkaline solution. In addition, the slag has a higher reactivity than the mine tailings due to the high temperatures to which it was subjected in the fusion process, which generates an amorphous structure ideal for geopolymerization [183].

Pavithra et al. [184] conducted a study in which they analyzed the variation of $\mathrm{SS} / \mathrm{NaOH}$ ratio in fly ash based geopolymers. From the study it was obtained that the optimum SS/NaOH ratio was 1.5 , obtaining a compressive strength of $46 \mathrm{MPa}$. Ratios with higher values obtained a decrease in compressive strength because higher sodium silicate contents implied an increase in the $\mathrm{Si} / \mathrm{Al}$ ratio, which in turn implied a decrease in compressive strength as discussed above.

In general, no clear pattern was found for the compressive strength obtained by varying the $\mathrm{SS} / \mathrm{NaOH}$ ratio (Figure 4). Some authors obtained the highest compressive strengths with SS/NaOH ratios between 1 and 1.5, while other authors found that an $\mathrm{SS} / \mathrm{NaOH}$ ratio of 2.5 is the optimum value to obtain the highest compressive strengths in geopolymers (Figure 5). It should be noted that the type of aluminosilicate source is an important factor to consider, since according to the data collected, fly ash based geopolymers obtained higher compressive strengths for any $\mathrm{SS} / \mathrm{NaOH}$ ratio than tailings based geopolymers, due to their low reactivity to alkaline solution. It should be noted that in most cases, a combination of sodium hydroxide and sodium silicate is used, because the latter alone is not capable of providing the necessary alkalinity to the system for a good dis- 
solution of the aluminosilicates. In addition, the use of sodium silicate is preferred because some aluminosilicate sources have low reactivity, such as mine tailings, so the addition of sodium silicate helps to increase the silicon content available for geopolymerization to occur.

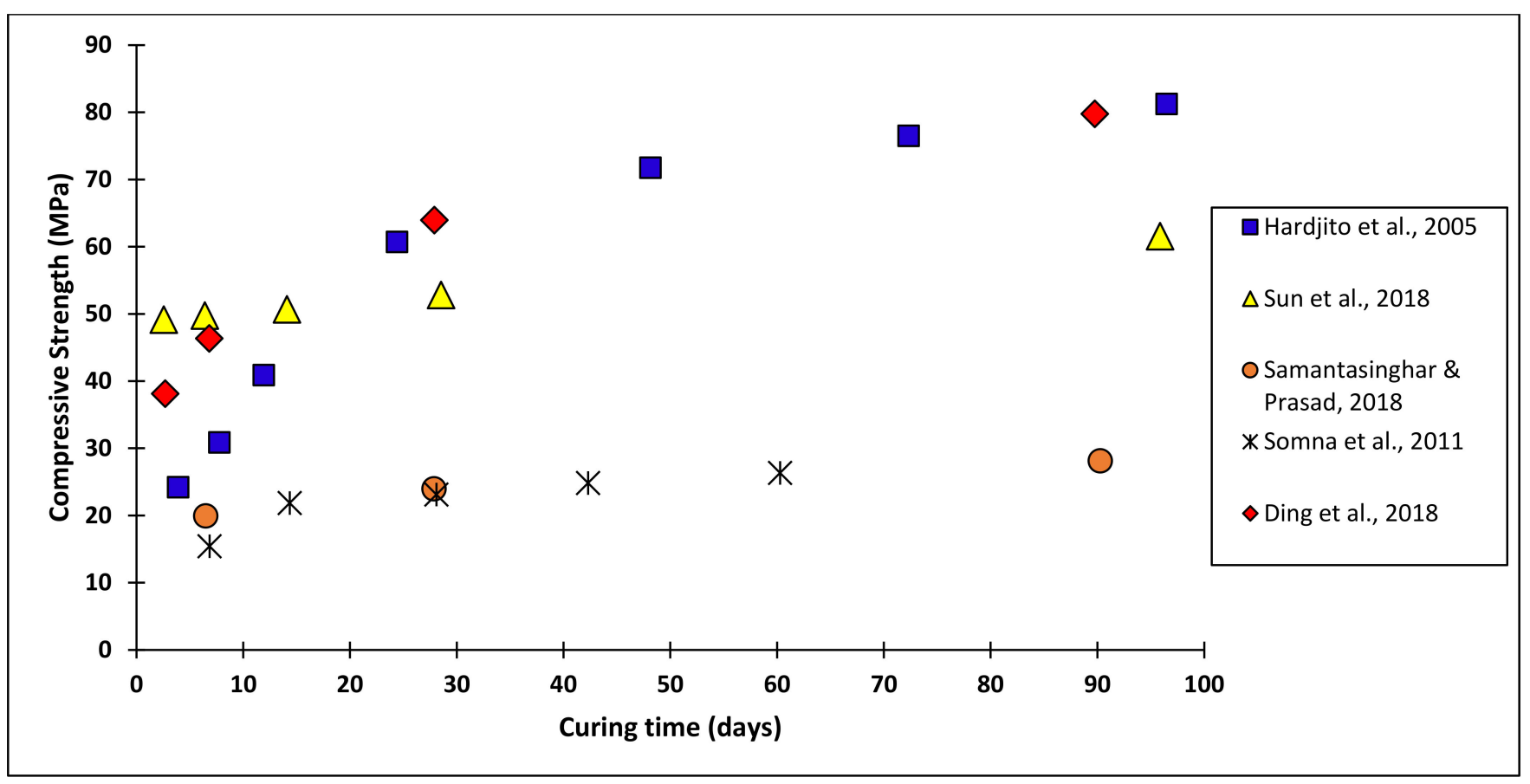

Figure 4. Graph compiling compressive strength versus curing time data obtained in previous investigations $[54,92,97,101,161]$.

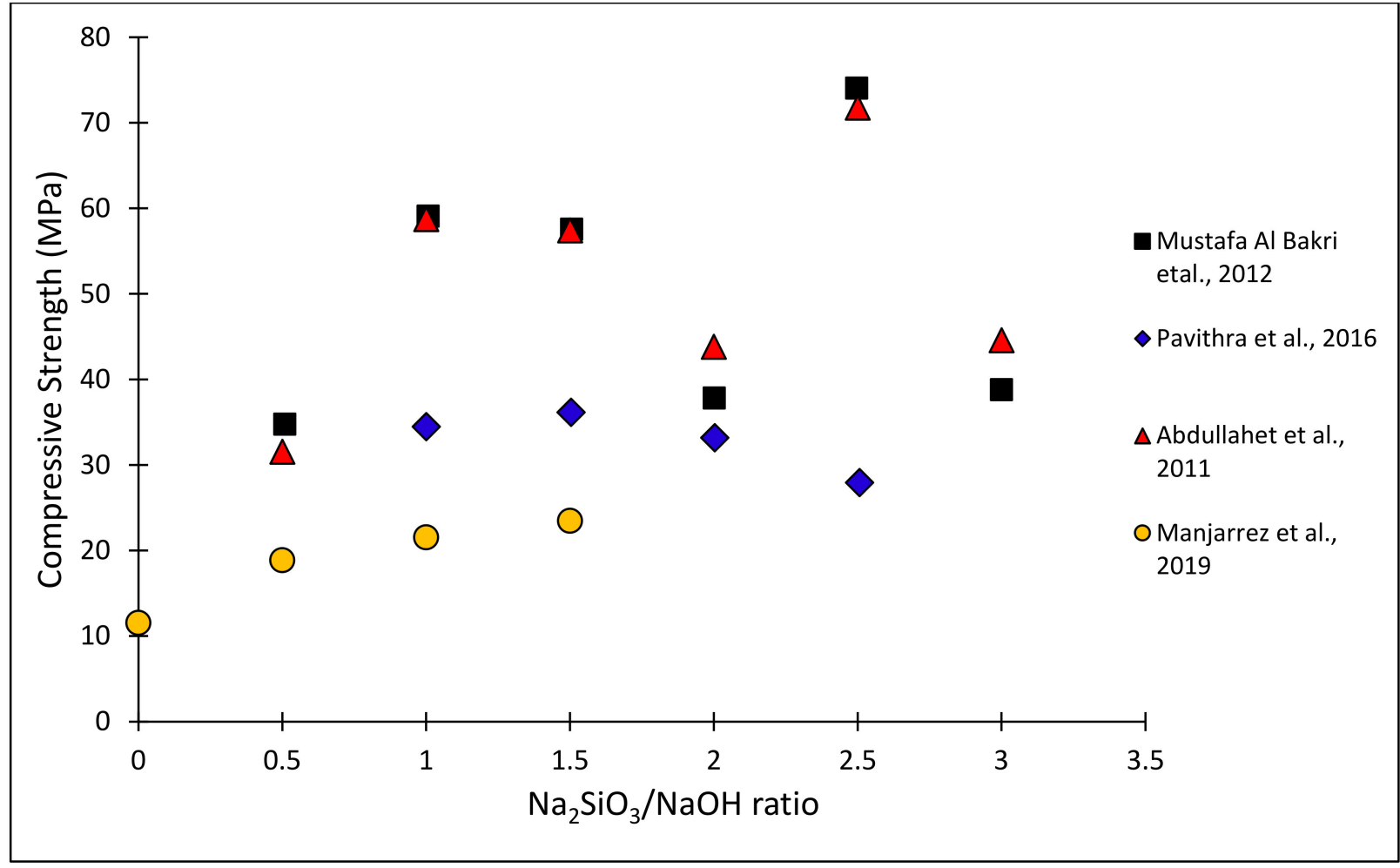

Figure 5. Graph compiling compressive strength data versus $\mathrm{Na}_{2} \mathrm{SiO}_{3} / \mathrm{NaOH}$ ratio obtained in previous investigations $[94,178,179,184]$. 
Aida Mohd Mortar et al. [185] analyzed the behavior of fly ash and aggregate-based geopolymers with different molarities and amounts of the alkaline activator. The amount of alkaline activator was quantified by the binder/aggregate ratio. From the results it was obtained that the compressive strength increases with the molarity of the activator up to $14 \mathrm{M}$, higher concentrations of the activator produced a decrease in the compressive strength. In the same way, the compressive strength increases as the percentage of alkaline activator increases, the optimum being found at 35\% activator and $65 \%$ aggregates, obtaining the best strength in all the concentrations analyzed.

A study by Somna et al. [54] where the effect of fly ash grinding prior to geopolymer formation was analyzed shows that increasing the concentration of the alkaline activator $(\mathrm{NaOH})$ up to $14 \mathrm{M}$ also increases the compressive strength of geopolymers for both unground fly ash (OFA) and ground fly ash (GFA) geopolymers. From this study it is also observed that pre-grinding the fly ash has a greater effect on the compressive strength of geopolymers than an increase in the concentration of the alkaline activator, mainly because there is a greater degree of release of the particles with the elements of interest for the formation of the solidifying gel.

A study by Ishwarya et al. [180] showed that an increase in the amount of alkaline activator in fly ash and slag based geopolymers produced an increase in the simple compressive strength. The optimum was found to be $30 \%$ by weight of alkaline activator in the total mixture. It should be noted that the samples cured for seven days showed no increase in compressive strength as the percentage of alkaline activator increased above $22 \%$. From this it can be deduced that the geopolymerization process is a slow process and requires long curing times to obtain a good compressive strength, especially when working with a high percentage of alkaline activator.

As previously mentioned, there are many types of activators to carry out the geopolymerization process, so the final product to be obtained, which is the geopolymer, will also depend on the type of activator to be used. Although the activators derived from sodium are the most common, lately activators based on other elements have been used where sodium is not so effective as an alkaline activator (Table 6). It should be noted that the use of wastes from other industries as alkaline activators for the production of geopolymers is currently being influenced, as is the case of calcium carbide waste in the production of acetylene gas.

Table 6. Summary of activators used for the formation of geopolymers.

\begin{tabular}{|c|c|c|}
\hline Aluminosilicate Source & Activator & Reference \\
\hline Copper tailings and fly ash & Sodium hydroxide & Zhang et al., [17] \\
\hline Fly ash & Sodium silicate and sodium hydroxide & Burduhos Nergis et al., [41] \\
\hline Garnet tailings and metakaolin & Sodium silicate & Wang et al., [70] \\
\hline Fly ash and ground granulated blast furnace slag & Sodium carbonate and sodium silicate & Ishwarya et al., [180] \\
\hline Gold mine tailings & Sugar mill lime sludge (Ca-based activator) & Opiso et al., [186] \\
\hline Metakaolin and commercial furnace slag & Potassium silicate & Panizza et al., [126] \\
\hline Fly ash & Calcium carbide residue and sodium silicate & Phetchuay et al., [187] \\
\hline
\end{tabular}

\subsection{Water Content}

Water content in geopolymeric mixtures is an important parameter to consider, since higher water contents produce more fluid and less viscous pastes, which favors their preparation process, but at the same time has repercussions on the compressive strength of the geopolymers once hardened.

Xie and Kayali [188] conducted a study analyzing the behavior of fly ash-based geopolymers with different water contents, cured with heat and at ambient temperature. The study showed that for both types of curing, lower water contents in the geopolymeric blends resulted in more compact structures and higher compressive strength development. In addition, it was observed that lower initial water contents resulted in a higher rate of compressive strength gain in geopolymers cured at ambient temperature, whereas with heat cured geopolymers, lower initial water content has no effect on the rate of compressive strength gain. 
It has been shown that the initial water content in geopolymer blends does not have much effect on the density of the pastes, but the density does have an important effect on the compressive strength [189].

A study by Khale and Chaudhary [23] shows that compressive strength decreases as the ratio of water-to-geopolymer solid by mass increases (Figure 6). This trend is analogous to water-to-cement ratio in the compressive strength in OPC. Although chemical processes involved in the formation of binders of both are entirely different [190]. The minimum water to cement ratio is approximately 0.4 by weight for Portland cement, whereas the fresh geopolymeric material is readily workable even at low liquid/solid ratio [191].

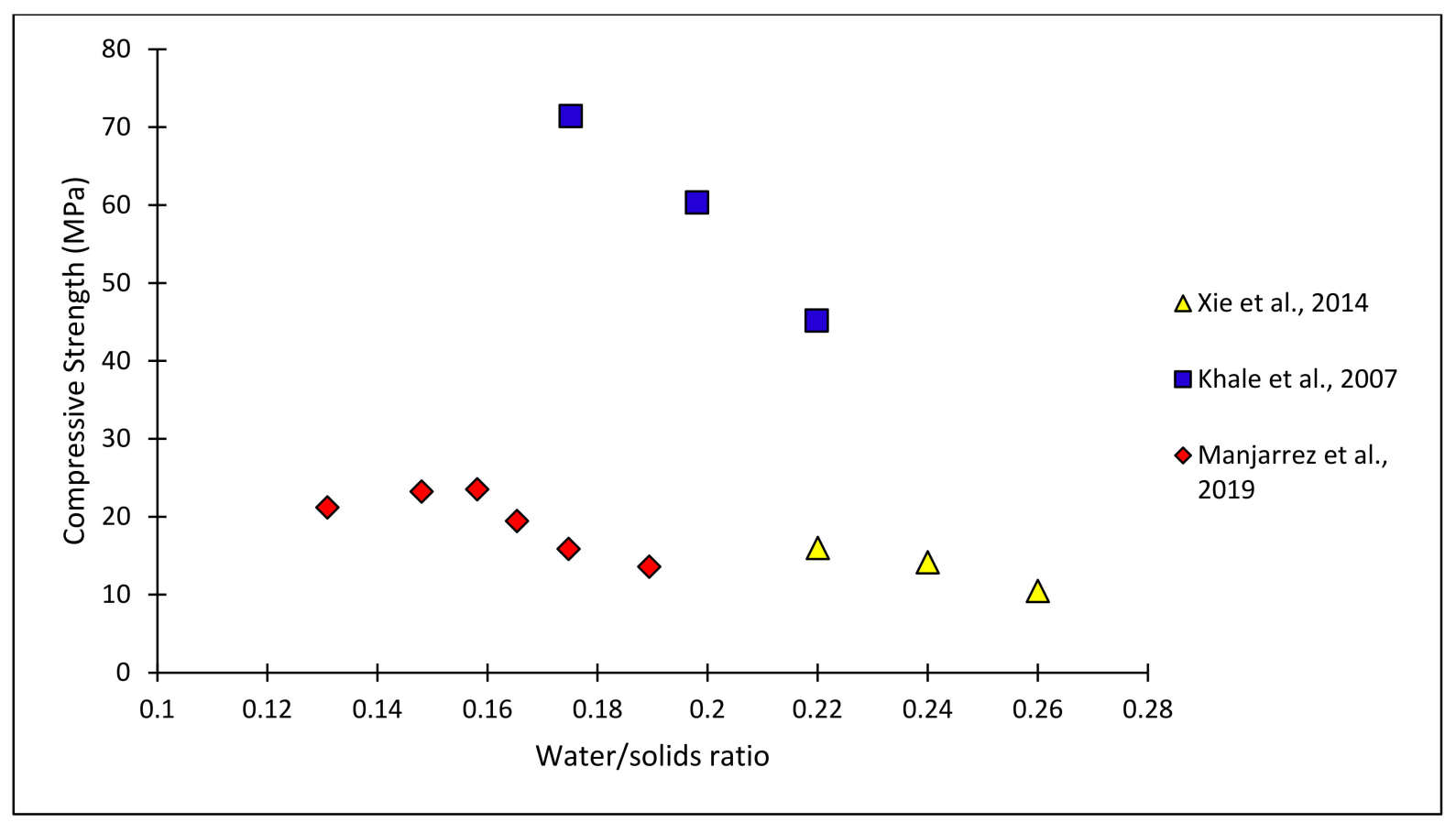

Figure 6. Graph compiling compressive strength data versus water/solids ratio obtained in previous investigations [23,94,188].

It has been shown that the initial water content in the formation of geopolymers is a fundamental factor in relation to the porosity of the product. Because higher water contents produce more porous geopolymers. Some authors relate this to the evaporation of free water, which produces porosity and residual stress [192,193].

In a study conducted by Manjarrez et al. [94], the effect of water content in geopolymers based on copper tailings and low calcium slag was analyzed. The results showed that in specimens cured for seven days at $60^{\circ} \mathrm{C}$, the compressive strength increased slightly with water content and then declined (Figure 6). According to the authors, this is due to the fact that with small amounts of water, lumps were formed in the mixture and large voids were formed in the specimens. When the water content increased, a maximum compressive strength of $23.5 \mathrm{MPa}$ with a w/s ratio of 0.158 was obtained. Further increases in water content led to lower compressive strengths due to reduced particle-particle interaction. According to other authors, this is due to the fact that a higher amount of water causes a lower degree of polycondensation [194].

From the data collected on strength versus water/solids ratio, it can be generally stated that higher water contents in geopolymer blends lead to lower compressive strengths (Figure 6); however, very low water contents can also lead to losses in the compressive strength of geopolymers as previously mentioned. It is worth mentioning that the water content to be used also depends on the source of aluminosilicates, and on the alkaline solution used, since different compositions generate mixtures with different fluidities, so the water content to be added also varies. In addition, a smaller amount of water implies using less amount of the activating reagent to reach the desired concentration, so 
optimizing the amount of water to be used is an important parameter to consider. Since the water contents used in geopolymeric mixtures are generally low, the pastes produced have high yield stresses and viscosities, so that their eventual transport and molding could be difficult.

\subsection{Effect of Presence of Calcium and Other Impurities}

Yip et al. [195] conducted an investigation and in it they observed the influence of calcium sources on geopolymerization. He used seven sources, two corresponding to processed sources and the rest were natural crystalline calcium sources. These sources were mixed with metakaolin in different proportions and sodium silicate, the latter at different ratios adjusted with $\mathrm{NaOH}(\mathrm{R})$. From these mixtures, the results of Table 7 were obtained, where each mixture was differentiated by label in the matrix column.

Table 7. Compressive strength with different amounts of calcium and alkaline solution [195].

\begin{tabular}{|c|c|c|c|c|c|c|c|c|c|c|}
\hline \multirow{2}{*}{$\begin{array}{l}\text { Calcium Silicate } \\
\text { Material (CS) }\end{array}$} & \multirow[b]{2}{*}{ MK/MK + CS } & \multicolumn{3}{|c|}{$\mathrm{R}=2.0$} & \multicolumn{3}{|c|}{$R=1.5$} & \multicolumn{3}{|c|}{$R=1.5$} \\
\hline & & Matrix & $\begin{array}{l}\text { 7-Day } \\
\text { [MPa] }\end{array}$ & $\begin{array}{l}\text { 28-Day } \\
\text { [MPa] }\end{array}$ & Matrix & $\begin{array}{l}\text { 7-Day } \\
\text { [MPa] }\end{array}$ & $\begin{array}{l}\text { 28-Day } \\
\text { [MPa] }\end{array}$ & Matrix & $\begin{array}{l}\text { 28-Day } \\
\text { [MPa] }\end{array}$ & $\begin{array}{l}\text { 7-Day } \\
\text { [MPa] }\end{array}$ \\
\hline None & 1 & S1 & 34.6 & 35.2 & S2 & 62 & 65 & S3 & 36.2 & 38.4 \\
\hline \multirow{2}{*}{ GGBFS } & 0.8 & A1 & 47.1 & 54.2 & A3 & 45.3 & 46.8 & A5 & 38.6 & 40.5 \\
\hline & 0.6 & A2 & 41.5 & 52.7 & A4 & 38.6 & 39.3 & A6 & 25.4 & 26.0 \\
\hline \multirow{2}{*}{ CEM } & 0.8 & B1 & 47.5 & 53.5 & B3 & 49.3 & 56.8 & B5 & 46.2 & 51.4 \\
\hline & 0.6 & B2 & 31.2 & 28.1 & B4 & 35.4 & 35.1 & B6 & 32.2 & 33.8 \\
\hline \multirow{2}{*}{ WOL } & 0.8 & $\mathrm{C} 1$ & $<5.0$ & 18.8 & $\mathrm{C} 3$ & 36.5 & 38.2 & $\mathrm{C} 5$ & 22.7 & 25.3 \\
\hline & 0.6 & $\mathrm{C} 2$ & $<5.0$ & 16.8 & $\mathrm{C} 4$ & 19.3 & 24.3 & C6 & 14 & 20.8 \\
\hline \multirow{2}{*}{ HRN } & 0.8 & E1 & $<5.0$ & 8.3 & E3 & 31.1 & 36.7 & E5 & 32.3 & 37 \\
\hline & 0.6 & E2 & $<5.0$ & 5.7 & E4 & 21.3 & 23.3 & E6 & 17.3 & 22.4 \\
\hline \multirow{2}{*}{ TRM } & 0.8 & G1 & $\mathrm{N} / \mathrm{A}$ & $\mathrm{N} / \mathrm{A}$ & G3 & 31.7 & 38.3 & G5 & 27.8 & 35.3 \\
\hline & 0.6 & G2 & $\mathrm{N} / \mathrm{A}$ & $\mathrm{N} / \mathrm{A}$ & G4 & 26.5 & 28.6 & G6 & 19.5 & 25.4 \\
\hline \multirow{2}{*}{ PRH } & 0.8 & $\mathrm{~F} 1$ & 6.7 & 14.3 & F3 & 32.2 & 39.4 & F5 & 29.5 & 36.4 \\
\hline & 0.6 & F2 & 6.2 & 11.5 & $\mathrm{~F} 4$ & 24 & 25.1 & F6 & 14 & 21.2 \\
\hline \multirow{2}{*}{ ANO } & 0.8 & D1 & $\mathrm{N} / \mathrm{A}$ & $\mathrm{N} / \mathrm{A}$ & D3 & 29.3 & 35.3 & D5 & 26.2 & 28.7 \\
\hline & 0.6 & D2 & $\mathrm{N} / \mathrm{A}$ & $\mathrm{N} / \mathrm{A}$ & D4 & 18.8 & 22.1 & D6 & 15.8 & 20.3 \\
\hline
\end{tabular}

Note: MK (metakaolin); GGBFS (ground granulated blast furnace slag); CEM (cement); WOL (wollastonite); HRN (hornblende); TRM (tremolite); PRH (prehnite); ANO (anorthite).

The results show that the dissolution of calcium in sources processed in a low alkalinity system provides good compressive strength due to the formation of CSH (Calcium Silicate Hydrate) gel [196] that coexists with the geopolymer gel (NASH), which subsequently complement each other and form a mostly amorphous structure that provides a better mechanical behavior. Very little calcium dissolves from natural sources, thus preventing the formation of $\mathrm{CSH}$ gel to form and causing the calcium crystals to interrupt the geopolymer gel. This indicates that the crystal disrupts the amorphous gel structure and stiffens the material, subsequently generating cracks around it, and reducing the compressive strength.

In high alkalinity systems (higher concentration of $\mathrm{NaOH}$ ), the formation of NASH gel is predominant, where the role of calcium is less influential in the final product as it cannot generate a CSH gel that contributes to the geopolymer gel or a large number of crystals that disrupts the amorphous structure of the gel. Therefore, the dissolution of calcium does not have a decisive impact on the compressive strength [195].

Yip et al. [195] focused on replacing part of the aluminosilicate source with calcium. Similarly, Tian et al. [197] studied the effect of replacing part of the alkaline activator $(\mathrm{NaOH})$ with calcium oxide $(\mathrm{CaO})$ produced industrially to form a geopolymer based on copper tailings from China with the same composition of their work when varying the temperature cured [81] and fly ash. It was observed that replacing $20 \%$ of the alkaline activator with $\mathrm{CaO}$ provides a greater compressive strength; however, this slightly reduces the compressive strength in the long term (28 days of aging at ambient conditions) since the best strength was obtained within seven days. Moreover, by means of micrographs, it 
was observed that $\mathrm{Si}, \mathrm{Al}$, and $\mathrm{Na}$ accumulate in a zone that would correspond to the NASH gel and the zone with absence of these elements where the Ca concentration predominates implies that there was no interaction of Ca with the rest of the elements to form a CSH gel.

Pachecho-Torgal and Jalali [198] studied how the presence of $\mathrm{Ca}(\mathrm{OH})_{2}$ influences the curing time at ambient conditions and the hydroxide concentration to obtain different compressive strengths when using tungsten tailings as a source of aluminosilicates (considering that they performed a heat treatment prior to tailing at $950{ }^{\circ} \mathrm{C}$ for $2 \mathrm{~h}$ to generate more soluble phases). In the study, a phenomenon similar to that described above was observed, where the higher the alkalinity of the system, the greater the gain in compressive strength, with this effect being more noticeable the longer the curing time. Regarding the presence of $\mathrm{Ca}(\mathrm{OH})_{2}$, it was observed that the compressive strength achieves an optimum point when the calcium content rises to $10 \%$, and higher amounts of calcium hydroxide subsequently led to a loss of compressive strength.

A study conducted by Yousefi Oderji et al. [199] in which they studied the behavior of fly ash based geopolymers with different amounts of high calcium slag, shows that an increase in the slag content leads to an increase in the compressive strength of the geopolymers, due to the high $\mathrm{CaO}$ content in the slag [162], the optimum point being a $15 \%$ replacement of fly ash by slag. The high $\mathrm{CaO}$ content in the fly ash can increase the compressive strength due to additional hydration reaction that may take place [200]. This can be attributed to the formation of C-A-S-H gels, which would reduce the porosity and condense the microstructure of alkali activated geopolymer matrix [113,201-204].

Fly ash and slags often contain considerable calcium, in which case coexistence of geopolymer gel and calcium aluminosilicate hydrate (C-A-S-H) is often observed [205]. Additionally, $\mathrm{CaO}$ content in the fly ash have significant effect on the setting time of geopolymer concrete [206].

Komnitsas et al. [207] studied the behavior of a geopolymer synthesized from an ironrich slag activated with $\mathrm{KOH}$, to which he added different types of nitrates and sulfates in different amounts. From the results obtained, it was observed that, except for the case of lead nitrates and sulfates, which decrease the compressive strength more slowly, the compressive strength drops drastically when adding nitrates and sulfates of any type, highlighting that having a $1 \% w / w$ of chromium nitrate, and the geopolymer was no longer formed. The behavior of copper nitrates and sulfates are like each other along with nickel nitrate. Looking for heavy metals, it can be determined that nitrates have a more negative behavior than sulfates. This can be explained by the fact that nitrates and sulfates rapidly consume the moles of $\mathrm{KOH}$, especially chromium, which its nitrate variant consumes between 80 and $100 \%$ of potassium hydroxide. The rest of the nitrates and sulfates can consume around $20 \%$ to $100 \%$ of the moles of the alkaline solution, except for lead, which in its nitrate variant managed to consume up to $60 \%$ of $\mathrm{KOH}$. This prevents enough moles of the alkaline solution to dissolve the silicon and aluminum from the source and the geopolymer to form.

In summary, Table 8 presents the data collected on impurities and how they were presented, also how their influence and the effect they had on compressive strength were evaluated. It can be mentioned that the addition of calcium in low amounts (not exceeding $20 \%$ by weight) are favorable for the production of geopolymers because they increase the compressive strength of these, due to the effect they have on the formation of gels that coexist with the NASH geopolymer gel. This calcium can come from the aluminosilicate source as well as from the alkaline activator, being the effect produced by this calcium dependent on the source from which it is obtained. 
Table 8. Summary on impurities in the formation of geopolymers.

\begin{tabular}{|c|c|c|c|c|c|c|c|}
\hline Source & Impurity & Type & Experiment & Effect & Optimal Point & UCS (MPa) & Reference \\
\hline Metakaolin & Calcium & $\begin{array}{l}\text { Processing (slag } \\
\text { and cement) and } \\
\text { natural crystals }\end{array}$ & $\begin{array}{l}\text { Aluminosilicate } \\
\text { source } \\
\text { replacement }\end{array}$ & $\begin{array}{l}\text { Processed: positive to low } \\
\text { alkalinity. Natural } \\
\text { crystals: negative at low } \\
\text { alkalinity. At high } \\
\text { alkalinity the effect is null } \\
\text { for both types. }\end{array}$ & $20 \%$ (cement) & 56.8 & Yip et al. [195]. \\
\hline Tailings & Calcium & Calcium oxide & $\begin{array}{l}\text { Alkaline solution } \\
\text { replacement }\end{array}$ & Positive at optimal point & $20 \%$ & $\sim 40$ & Tian et al. [197]. \\
\hline Tailings & Calcium & $\begin{array}{l}\text { Calcium } \\
\text { hydroxide }\end{array}$ & $\begin{array}{l}\text { Presence in the } \\
\text { source of } \\
\text { aluminosilicates }\end{array}$ & Positive at optimal point & $10 \%$ & 70 & $\begin{array}{c}\text { Pacheco-Torgal and } \\
\text { Jalali [198] }\end{array}$ \\
\hline Iron slag & $\begin{array}{l}\text { Lead, nickel, } \\
\text { copper, and } \\
\text { chromium }\end{array}$ & $\begin{array}{l}\text { Sulfates and } \\
\text { nitrates }\end{array}$ & $\begin{array}{l}\text { Added in the } \\
\text { mix for the } \\
\text { formation of the } \\
\text { geopolymer }\end{array}$ & Negative & - & - & $\begin{array}{c}\text { Komnitsas et al. } \\
\text { [207]. }\end{array}$ \\
\hline
\end{tabular}

It can be assumed that the presence of calcium can have positive effects on the formation of the geopolymer if it can be controlled in its proportion, either in the source of aluminosilicates or in the alkaline solution. Given that calcium is present in the source of aluminosilicates, it would only have an effect on the formation if it is presented as calcium hydroxide, as we are aware calcium from processed sources and as natural crystals will have no effect on the compressive strength, as the formation of geopolymers occurs in a highly alkaline system. Finally, the presence of heavy metals such as lead, nickel, copper, and chromium have negative effects on the compressive strength, so their content should be analyzed when choosing the source of aluminosilicates that we would prefer to use.

Previous studies have proven the ability of geopolymers to encapsulate toxic elements from industrial wastes, so that these wastes can be reused and are not hazardous to the environment. By means of leachability tests, it has been obtained that geopolymers encapsulate elements such as $\mathrm{Pb}, \mathrm{Cu}, \mathrm{Zn}$, and As, whereby using cementation methods, the leachability of industrial wastes containing these elements has been drastically reduced $[208,209]$.

\section{Conclusions}

From the findings of the previous studies that investigated the mechanical properties of geopolymers. The conclusions are summarized as follows:

It has been shown that the compressive strength of geopolymers depends mainly on their chemical composition, a fundamental parameter to be considered being the source of aluminosilicates. Elements present in the source such as silicon and aluminum are fundamental for the formation of the N-A-S-H gel, which is responsible for the hardening of geopolymers. This is why the ratio between these elements is an important parameter to consider in the production of geopolymers, in order to obtain good compressive strengths. On the other hand, it has been demonstrated that the different aluminosilicate sources have different reactivities against alkaline agents, mainly due to their origin. Sources with higher reactivity have been shown to produce geopolymers with higher strengths.

The geopolymeric reactivity of aluminosilicate materials can be significantly improved by using several techniques. These activation processes enhance reactivity by increasing the rate and extent to which silicon and aluminum species from the activated materials dissolve in alkaline medium [210].

It is evident that temperature and time play a fundamental role in the curing of geopolymers, showing that higher temperatures and curing times promote the formation of the N-A-S-H gel and consequently the hardening and strength gain of the geopolymers. However, this depends on the composition of the geopolymer, since it has been demonstrated in several studies that geopolymers can be cured at ambient temperature without the need to apply external heat. Although applying heat favors the geopolymerization reactions, it is not necessary in all cases because it can be complemented by applying longer curing times to geopolymers cured at ambient temperature. 
With respect to alkaline activators, in most cases sodium derivatives were used. Some studies used a 100\% sodium hydroxide solution, while others used a mixture of sodium hydroxide and sodium silicate, because it has been shown that the latter results in geopolymers with better microstructures, denser matrices, and, consequently, improved compressive strength. In addition, most studies show that an increase in the amount of alkaline activator causes an increase in compressive strength.

Water content is an important parameter to consider in the production of geopolymers. It has been observed that lower amounts of water produce geopolymers with better compressive strengths, and lower water use means less use of alkaline reagents. On the other hand, a higher water content produces geopolymer pastes of higher fluidity but obtaining a lower resistance in the already hardened geopolymers.

Small amounts of calcium have proven to be beneficial for obtaining good compressive strength due to the formation of the C-A-S-H gel that coexists with the N-A-S-H gel, while high amounts of calcium have proven to be detrimental to the compressive strength of geopolymers. This happens too in the presence of heavy metals such as copper, chromium, and nickel with a negative influence in the compressive strength.

Author Contributions: H.C. (Hengels Castillo): Writing-review \& editing, Principal investigator, Project administration, Resources, Supervision, Validation; H.C. (Humberto Collado): Writingreview \& editing, Investigation; T.D.: Writing—review \& editing, Investigation; S.S.: Writing—review \& editing, Investigation; M.V.: Resources, Supervision, Validation; P.G.: Resources, Supervision, Project administration; S.P.: Writing-review \& editing, Investigation, Validation, Supervision. All authors have read and agreed to the published version of the manuscript.

Funding: This research received no external funding.

Acknowledgments: We are grateful for the support of this research project to the Consulting Company JRI Engineering from Chile (https:/ / www.jri.cl/, accessed on 16 November 2021) and the Center for Research in Sustainable Mining CIMS-JRI (https://www.cimsjri.cl/, accessed on 16 November 2021).

Conflicts of Interest: Authors state no conflict of interest.

\section{References}

1. Wang, H.; Li, H.; Yan, F. Synthesis and mechanical properties of metakaolinite-based geopolymer. Colloids Surf. A Physicochem. Eng. Asp. 2005, 268, 1-6. [CrossRef]

2. Zannerni, G.M.; Fattah, K.P.; Al-Tamimi, A.K. Ambient-cured geopolymer concrete with single alkali activator. Sustain. Mater. Technol. 2020, 23, e00131. [CrossRef]

3. Farhan, K.Z.; Johari, M.A.M.; Demirboğa, R. Assessment of important parameters involved in the synthesis of geopolymer composites: A review. Constr. Build. Mater. 2020, 264, 120276. [CrossRef]

4. Sun, Q.; Tian, S.; Sun, Q.; Li, B.; Cai, C.; Xia, Y.; Wei, X.; Mu, Q. Preparation and microstructure of fly ash geopolymer paste backfill material. J. Clean. Prod. 2019, 225, 376-390. [CrossRef]

5. Zhang, N.; Hedayat, A.; Sosa, H.G.B.; Cárdenas, J.J.G.; Álvarez, G.E.S.; Rivera, V.B.A. Damage evaluation and deformation behavior of mine tailing-based Geopolymer under uniaxial cyclic compression. Ceram. Int. 2021, 47, 10773-10785. [CrossRef]

6. Li, Y.; Min, X.; Ke, Y.; Liu, D.; Tang, C. Preparation of red mud-based geopolymer materials from MSWI fly ash and red mud by mechanical activation. Waste Manag. 2019, 83, 202-208. [CrossRef] [PubMed]

7. Singh, B.; Ishwarya, G.; Gupta, M.; Bhattacharyya, S. Geopolymer concrete: A review of some recent developments. Constr. Build. Mater. 2015, 85, 78-90. [CrossRef]

8. Khan, K.A.; Raut, A.; Chandrudu, C.R.; Sashidhar, C. Design and development of sustainable geopolymer using industrial copper byproduct. J. Clean. Prod. 2021, 278, 123565. [CrossRef]

9. Kashani, A.; Provis, J.; Qiao, G.; van Deventer, J.S. The interrelationship between surface chemistry and rheology in alkali activated slag paste. Constr. Build. Mater. 2014, 65, 583-591. [CrossRef]

10. Kiventerä, J.; Perumal, P.; Yliniemi, J.; Illikainen, M. Mine tailings as a raw material in alkali activation: A review. Int. J. Miner. Met. Mater. 2020, 27, 1009-1020. [CrossRef]

11. Çetintaş, R.; Soyer-Uzun, S. Relations between structural characteristics and compressive strength in volcanic ash based one-part geopolymer systems. J. Build. Eng. 2018, 20, 130-136. [CrossRef]

12. Dineshkumar, M.; Umarani, C. Effect of Alkali Activator on the Standard Consistency and Setting Times of Fly Ash and GGBS-Based Sustainable Geopolymer Pastes. Adv. Civ. Eng. 2020, 2020, 1-10. [CrossRef] 
13. Chen-Tan, N.W.; Van Riessen, A.; Ly, C.V.; Southam, D.C. Determining the Reactivity of a Fly Ash for Production of Geopolymer. J. Am. Ceram. Soc. 2009, 92, 881-887. [CrossRef]

14. Rifaai, Y.; Yahia, A.; Mostafa, A.; Aggoun, S.; Kadri, E.-H. Rheology of fly ash-based geopolymer: Effect of NaOH concentration. Constr. Build. Mater. 2019, 223, 583-594. [CrossRef]

15. Nadoushan, M.J.; Ramezanianpour, A.A. The effect of type and concentration of activators on flowability and compressive strength of natural pozzolan and slag-based geopolymers. Constr. Build. Mater. 2016, 111, 337-347. [CrossRef]

16. Görhan, G.; Aslaner, R.; Şinik, O. The effect of curing on the properties of metakaolin and fly ash-based geopolymer paste. Compos. Part B Eng. 2016, 97, 329-335. [CrossRef]

17. Zhang, L.; Ahmari, S.; Zhang, J. Synthesis and characterization of fly ash modified mine tailings-based geopolymers. Constr. Build. Mater. 2011, 25, 3773-3781. [CrossRef]

18. Ding, Y.; Dai, J.-G.; Shi, C.-J. Mechanical properties of alkali-activated concrete: A state-of-the-art review. Constr. Build. Mater. 2016, 127, 68-79. [CrossRef]

19. Zhang, H.Y.; Kodur, V.; Wu, B.; Yan, J.; Yuan, Z.S. Effect of temperature on bond characteristics of geopolymer concrete. Constr. Build. Mater. 2018, 163, 277-285. [CrossRef]

20. Lloyd, N.A.; Rangan, B.V. Geopolymer Concrete: A Review of Development and Opportunities. pp. 25-27. Available online: http:/ / cipremier.com/100035037www.cipremier.com (accessed on 18 September 2021).

21. White, C.; Provis, J.L.; Proffen, T.; Van Deventer, J.S.J. The Effects of Temperature on the Local Structure of Metakaolin-Based Geopolymer Binder: A Neutron Pair Distribution Function Investigation. J. Am. Ceram. Soc. 2010, 93, 3486-3492. [CrossRef]

22. Dang, J.; Shen, X.; Castel, A.; Aldred, A.C.A.J. Monitoring Apparent pH Value in Geopolymer Concrete Using Glass Electrode. In Proceedings of the 33rd International Symposium on Automation and Robotics in Construction (ISARC); International Association for Automation and Robotics in Construction (IAARC), Auburn, AL, USA, 18-21 July 2016; pp. 547-554.

23. Khale, D.; Chaudhary, R. Mechanism of geopolymerization and factors influencing its development: A review. J. Mater. Sci. 2007, 42, 729-746. [CrossRef]

24. Chen, I.A.; Hargis, C.W.; Juenger, M.C. Understanding expansion in calcium sulfoaluminate-belite cements. Cem. Concr. Res. 2012, 42, 51-60. [CrossRef]

25. Lahoti, M.; Narang, P.; Tan, K.H.; Yang, E.-H. Mix design factors and strength prediction of metakaolin-based geopolymer. Ceram. Int. 2017, 43, 11433-11441. [CrossRef]

26. Chen, X.; Mondal, P. Effects of $\mathrm{NaOH}$ amount on condensation mechanism to form aluminosilicate, case study of geopolymer gel synthesized via sol-gel method. J. Sol-Gel Sci. Technol. 2020, 96, 589-603. [CrossRef]

27. Keyte, L. Fly ash glass chemistry and inorganic polymer cements. In Geopolymers; Elsevier: Amsterdam, The Netherlands, 2009; pp. 15-36.

28. Duxson, P.; Provis, J.; Lukey, G.C.; Mallicoat, S.W.; Kriven, W.M.; van Deventer, J.S. Understanding the relationship between geopolymer composition, microstructure and mechanical properties. Colloids Surf. A Physicochem. Eng. Asp. 2005, 269, 47-58. [CrossRef]

29. Duxson, P.; Lukey, G.C.; Separovic, F.; van Deventer, J.S.J. Effect of Alkali Cations on Aluminum Incorporation in Geopolymeric Gels. Ind. Eng. Chem. Res. 2005, 44, 832-839. [CrossRef]

30. Duxson, P.; Mallicoat, S.; Lukey, G.; Kriven, W.; van Deventer, J. The effect of alkali and Si/Al ratio on the development of mechanical properties of metakaolin-based geopolymers. Colloids Surf. A Physicochem. Eng. Asp. 2007, 292, 8-20. [CrossRef]

31. Wan, Q.; Rao, F.; Song, S.; García, R.E.; Estrella, R.M.; Patiño, C.A.L.; Zhang, Y. Geopolymerization reaction, microstructure and simulation of metakaolin-based geopolymers at extended $\mathrm{Si} / \mathrm{Al}$ ratios. Cem. Concr. Compos. 2017, 79, 45-52. [CrossRef]

32. Perera, D.S.; Uchida, O.; Vance, E.R.; Finnie, K.S. Influence of curing schedule on the integrity of geopolymers. J. Mater. Sci. 2007, 42, 3099-3106. [CrossRef]

33. Steveson, M.; Sagoe-Crentsil, K. Relationships between composition, structure and strength of inorganic polymers. J. Mater. Sci. 2005, 40, 2023-2036. [CrossRef]

34. Rodríguez, E.; Mejía de Gutiérrez, R.; Bernal, S.; Gordillo, M. Effect of the $\mathrm{S}_{\mathrm{i}} \mathrm{O}_{2} / \mathrm{Al}_{2} \mathrm{O}_{3}$ and $\mathrm{Na}_{2} \mathrm{O} / \mathrm{S}_{\mathrm{i}} \mathrm{O}_{2}$ ratios on the properties of geopolymers based on MK. Revista Facultad de Ingeniería Universidad de Antioquia 2009, 49, 30-41.

35. Subaer. Influence of Aggregate on the Microstructure of Geopolymer. Ph.D. Thesis, Curtin University, Bentley, Australia, 2004.

36. Angelone, S.; Garibay, M.T.; Cauhapé Casaux, M. Permeabilidad de suelos. Geol. y Geotec-Permeabilidad Suelos. 2006. Available online: https:/ / www.fceia.unr.edu.ar/geologiaygeotecnia/PERMEABILIDAD.pdf (accessed on 18 September 2021).

37. Aredes, F.; Campos, T.; Machado, J.; Sakane, K.; Thim, G.; Brunelli, D. Effect of cure temperature on the formation of metakaolinitebased geopolymer. Ceram. Int. 2015, 41, 7302-7311. [CrossRef]

38. Sun, Z.; Lin, X.; Vollpracht, A. Pervious concrete made of alkali activated slag and geopolymers. Constr. Build. Mater. 2018, 189, 797-803. [CrossRef]

39. Muñiz-Villarreal, M.S.; Manzano-Ramírez, A.; Sampieri-Bulbarela, S.; Gasca-Tirado, J.R.; Reyes-Araiza, J.L.; Rubio-Ávalos, J.C.; Pérez-Bueno, J.J.; Apatiga, L.M.; Zaldivar-Cadena, A.; Amigó, V. The effect of temperature on the geopolymerization process of a metakaolin-based geopolymer. Mater. Lett. 2011, 65, 995-998. [CrossRef]

40. Provis, J.; Palomo, A.; Shi, C. Advances in understanding alkali-activated materials. Cem. Concr. Res. 2015, 78, 110-125. [CrossRef]

41. Nergis, D.D.B.; Vizureanu, P.; Corbu, O. Synthesis and Characteristics of Local Fly Ash Based Geopolymers Mixed with Natural Aggregates. Rev. De Chim. 2019, 70, 1262-1267. [CrossRef] 
42. Atis, C.; Görür, E.; Karahan, O.; Bilim, C.; Ilkentapar, S.; Luga, E. Very high strength (120MPa) class F fly ash geopolymer mortar activated at different $\mathrm{NaOH}$ amount, heat curing temperature and heat curing duration. Constr. Build. Mater. 2015, 96, 673-678. [CrossRef]

43. Joseph, B.; Mathew, G. Influence of aggregate content on the behavior of fly ash based geopolymer concrete. Sci. Iran. 2012, 19, 1188-1194. [CrossRef]

44. Paudel, S.R.; Yang, M.; Gao, Z. pH Level of Pore Solution in Alkali-Activated Fly-Ash Geopolymer Concrete and Its Effect on ASR of Aggregates with Different Silicate Contents. J. Mater. Civ. Eng. 2020, 32, 04020257. [CrossRef]

45. Duan, P.; Yan, C.; Zhou, W.; Luo, W. Fresh properties, mechanical strength and microstructure of fly ash geopolymer paste reinforced with sawdust. Constr. Build. Mater. 2016, 111, 600-610. [CrossRef]

46. Azimi, E.A.; Abdullah, M.M.A.B.; Vizureanu, P.; Salleh, M.A.A.M.; Sandu, A.V.; Chaiprapa, J.; Yoriya, S.; Hussin, K.; Aziz, I.H. Strength Development and Elemental Distribution of Dolomite/Fly Ash Geopolymer Composite under Elevated Temperature. Materials 2020, 13, 1015. [CrossRef] [PubMed]

47. Hajimohammadi, A.; Ngo, T.; Kashani, A. Sustainable one-part geopolymer foams with glass fines versus sand as aggregates. Constr. Build. Mater. 2018, 171, 223-231. [CrossRef]

48. Burduhos Nergis, D.D.; Abdullah, M.M.A.B.; Sandu, A.V.; Vizureanu, P. XRD and TG-DTA Study of New Alkali Activated Materials Based on Fly Ash with Sand and Glass Powder. Materials 2020, 13, 343. [CrossRef] [PubMed]

49. Lalitha, G.; Sasidhar, C.; Ramachandrudu, C. A review paper on strength and durability studies on concrete fine aggregate replaced with recycled crushed glass. Int. J. Civ. Eng. Technol. 2017, 8, 199-202.

50. Luhar, S.; Cheng, T.-W.; Nicolaides, D.; Luhar, I.; Panias, D.; Sakkas, K. Valorisation of glass wastes for the development of geopolymer composites-Durability, thermal and microstructural properties: A review. Constr. Build. Mater. 2019, 222, 673-687. [CrossRef]

51. Wang, W.-C.; Chen, B.-T.; Wang, H.-Y.; Chou, H.-C. A study of the engineering properties of alkali-activated waste glass material (AAWGM). Constr. Build. Mater. 2016, 112, 962-969. [CrossRef]

52. Shaikh, F.U.A. Mechanical and durability properties of fly ash geopolymer concrete containing recycled coarse aggregates. Int. J. Sustain. Built Environ. 2016, 5, 277-287. [CrossRef]

53. Matalkah, F.; Xu, L.; Wu, W.; Soroushian, P. Mechanochemical synthesis of one-part alkali aluminosilicate hydraulic cement. Mater. Struct. 2016, 50, 97. [CrossRef]

54. Somna, K.; Jaturapitakkul, C.; Kajitvichyanukul, P.; Chindaprasirt, P. NaOH-activated ground fly ash geopolymer cured at ambient temperature. Fuel 2011, 90, 2118-2124. [CrossRef]

55. Deb, P.S.; Nath, P.; Sarker, P. The effects of ground granulated blast-furnace slag blending with fly ash and activator content on the workability and strength properties of geopolymer concrete cured at ambient temperature. Mater. Des. 2014, 62, 32-39. [CrossRef]

56. Fang, G.; Bahrami, H.; Zhang, M. Mechanisms of autogenous shrinkage of alkali-activated fly ash-slag pastes cured at ambient temperature within 24 h. Constr. Build. Mater. 2018, 171, 377-387. [CrossRef]

57. Temuujin, J.; Williams, R.; van Riessen, A. Effect of mechanical activation of fly ash on the properties of geopolymer cured at ambient temperature. J. Mater. Process. Technol. 2009, 209, 5276-5280. [CrossRef]

58. Bignozzi, M.C.; Manzi, S.; Natali, M.E.; Rickard, W.; van Riessen, A. Room temperature alkali activation of fly ash: The effect of $\mathrm{Na}_{2} \mathrm{O} / \mathrm{S}_{\mathrm{i}} \mathrm{O}_{2}$ ratio. Constr. Build. Mater. 2014, 69, 262-270. [CrossRef]

59. Xiaolong, Z.; Shiyu, Z.; Hui, L.; Yingliang, Z. Disposal of mine tailings via geopolymerization. J. Clean. Prod. 2021, $284,124756$. [CrossRef]

60. Wan, Q.; Rao, F.; Song, S.; Patiño, C.A.L.; Ma, Y.; Yin, W. Consolidation of mine tailings through geopolymerization at ambient temperature. J. Am. Ceram. Soc. 2018, 102, 2451-2461. [CrossRef]

61. Al-Majidi, M.H.; Lampropoulos, A.; Cundy, A.; Meikle, S. Development of geopolymer mortar under ambient temperature for in situ applications. Constr. Build. Mater. 2016, 120, 198-211. [CrossRef]

62. Zhang, H.; Li, L.; Sarker, P.K.; Long, T.; Shi, X.; Wang, Q.; Cai, G. Investigating Various Factors Affecting the Long-Term Compressive Strength of Heat-Cured Fly Ash Geopolymer Concrete and the Use of Orthogonal Experimental Design Method. Int. J. Concr. Struct. Mater. 2019, 13, 63. [CrossRef]

63. Riahi, S.; Nemati, A.; Khodabandeh, A.; Baghshahi, S. The effect of mixing molar ratios and sand particles on microstructure and mechanical properties of metakaolin-based geopolymers. Mater. Chem. Phys. 2020, 240, 122223. [CrossRef]

64. Yunsheng, Z.; Wei, S.; Zongiin, L. Composition design and microstructural characterization of calcined kaolin-based geopolymer cement. Appl. Clay Sci. 2010, 47, 271-275. [CrossRef]

65. Rowles, M.; O'Connor, B. Chemical optimisation of the compressive strength of aluminosilicate geopolymers synthesised by sodium silicate activation of metakaolinite. J. Mater. Chem. 2003, 13, 1161-1165. [CrossRef]

66. Rowles, M.R.; O'Connor, B.H. Chemical and Structural Microanalysis of Aluminosilicate Geopolymers Synthesized by Sodium Silicate Activation of Metakaolinite. J. Am. Ceram. Soc. 2009, 92, 2354-2361. [CrossRef]

67. Singh, S.; Aswath, M.; Ranganath, R. Effect of mechanical activation of red mud on the strength of geopolymer binder. Constr. Build. Mater. 2018, 177, 91-101. [CrossRef]

68. Xu, J.; Zhang, D. Multifunctional structural supercapacitor based on graphene and geopolymer. Electrochim. Acta 2017, 224, 105-112. [CrossRef] 
69. Falayi, T. Effect of potassium silicate and aluminate on the stabilisation of gold mine tailings. Proc. Inst. Civ. Eng. Waste Resour. Manag. 2019, 172, 56-63. [CrossRef]

70. Wang, A.; Liu, H.; Hao, X.; Wang, Y.; Liu, X.; Li, Z. Geopolymer Synthesis Using Garnet Tailings from Molybdenum Mines. Minerals 2019, 9, 48. [CrossRef]

71. Kuranchie, F.A.; Shukla, S.K.; Habibi, D. Utilisation of iron ore mine tailings for the production of geopolymer bricks. Int. J. Min. Reclam. Environ. 2014, 30, 92-114. [CrossRef]

72. Zhao, S.; Xia, M.; Yu, L.; Huang, X.; Jiao, B.; Li, D. Optimization for the preparation of composite geopolymer using response surface methodology and its application in lead-zinc tailings solidification. Constr. Build. Mater. 2021, 266, 120969. [CrossRef]

73. Lahoti, M.; Wong, K.K.; Yang, E.-H.; Tan, K.H. Effects of Si/Al molar ratio on strength endurance and volume stability of metakaolin geopolymers subject to elevated temperature. Ceram. Int. 2018, 44, 5726-5734. [CrossRef]

74. Zribi, M.; Samet, B.; Baklouti, S. Effect of curing temperature on the synthesis, structure and mechanical properties of phosphatebased geopolymers. J. Non Cryst. Solids 2019, 511, 62-67. [CrossRef]

75. Heah, C.; Kamarudin, H.; Al Bakri, A.M.; Binhussain, M.; Luqman, M.; Nizar, I.K.; Ruzaidi, C.; Liew, Y.M. Effect of Curing Profile on Kaolin-based Geopolymers. Phys. Procedia 2011, 22, 305-311. [CrossRef]

76. Cheng, H.; Lin, K.-L.; Cui, R.; Hwang, C.-L.; Chang, Y.-M.; Cheng, T.-W. The effects of $\mathrm{SiO}_{2} / \mathrm{Na}_{2} \mathrm{O}$ molar ratio on the characteristics of alkali-activated waste catalyst-metakaolin based geopolymers. Constr. Build. Mater. 2015, 95, 710-720. [CrossRef]

77. Singh, G.B.; Subramaniam, K.V. Evaluation of sodium content and sodium hydroxide molarity on compressive strength of alkali activated low-calcium fly ash. Cem. Concr. Compos. 2017, 81, 122-132. [CrossRef]

78. Nagral, M.R.; Ostwal, T.; Chitawadagi, M.V. Effect Of Curing Temperature And Curing Hours On The Properties Of Geo-Polymer Concrete. Int. J. Comput. Eng. Res. 2014, 4, 2250-3005.

79. Manesh, S.B.; Madhukar, R.W.; Subhash, V.P. Effect of duration and temperature of curing on compressive strength of geopolymer concrete. Int. J. Eng. Innov. Technol. 2012, 1, 152-155.

80. Huang, B.; Feng, Q.; An, D.; Zhang, J. Use of Mine Tailings as Precast Construction Materials through Alkali Activation. Min. Met. Explor. 2019, 37, 251-265. [CrossRef]

81. Tian, X.; Xu, W.; Song, S.; Rao, F.; Xia, L. Effects of curing temperature on the compressive strength and microstructure of copper tailing-based geopolymers. Chemosphere 2020, 253, 126754. [CrossRef]

82. Law, D.W.; Adam, A.A.; Molyneaux, T.K.; Patnaikuni, I.; Wardhono, A. Long term durability properties of class F fly ash geopolymer concrete. Mater. Struct. 2014, 48, 721-731. [CrossRef]

83. Khan, M.; Castel, A.; Noushini, A. Carbonation of a low-calcium fly ash geopolymer concrete. Mag. Concr. Res. 2017, 69, 24-34. [CrossRef]

84. Zhang, Z.; Wang, H.; Provis, J.L.; Reid, A. Efflorescence: A Critical Challenge for Geopolymer Applications? In Proceedings of the Concrete Institute of Australia's Biennial National Conference 2013, Gold Coast, Australia, 16-18 October 2013.

85. Bernal, S. The resistance of alkali-activated cement-based binders to carbonation. In Handbook of Alkali-Activated Cements, Mortars and Concretes; Elsevier: Amsterdam, The Netherlands, 2015; pp. 319-332. [CrossRef]

86. Morandeau, A.; Thiéry, M.; Dangla, P. Investigation of the carbonation mechanism of CH and C-S-H in terms of kinetics, microstructure changes and moisture properties. Cem. Concr. Res. 2014, 56, 153-170. [CrossRef]

87. Bernal, S.A.; Provis, J.L.; Walkley, B.; Nicolas, R.S.; Gehman, J.D.; Brice, D.G.; Kilcullen, A.R.; Duxson, P.; Van Deventer, J.S. Gel nanostructure in alkali-activated binders based on slag and fly ash, and effects of accelerated carbonation. Cem. Concr. Res. 2013, 53, 127-144. [CrossRef]

88. Puertas, F.; Palacios, M.; Vázquez, T. Carbonation process of alkali-activated slag mortars. J. Mater. Sci. 2006, 41, 3071-3082. [CrossRef]

89. Pouhet, R.; Cyr, M. Carbonation in the pore solution of metakaolin-based geopolymer. Cem. Concr. Res. 2016, 88, 227-235. [CrossRef]

90. Oderji, S.Y.; Chen, B.; Jaffar, S.T.A. Effects of relative humidity on the properties of fly ash-based geopolymers. Constr. Build. Mater. 2017, 153, 268-273. [CrossRef]

91. Kong, D.; Sanjayan, J.; Sagoe-Crentsil, K. Factors affecting the performance of metakaolin geopolymers exposed to elevated temperatures. J. Mater. Sci. 2008, 43, 824-831. [CrossRef]

92. Hardjito, D.; Rangan, B.V. Development and Properties of Low-Calcium Fly Ash-Based Geopolymer Concrete; Curtin University of Technology: Perth, Australia, 2005. Available online: http://www.geopolymer.org/fichiers_pdf/curtin-flyash-GP-concretereport.pdf (accessed on 16 November 2021).

93. Ahmari, S.; Zhang, L.; Zhang, J. Effects of activator type/concentration and curing temperature on alkali-activated binder based on copper mine tailings. J. Mater. Sci. 2012, 47, 5933-5945. [CrossRef]

94. Manjarrez, L.; Nikvar-Hassani, A.; Shadnia, R.; Zhang, L. Experimental Study of Geopolymer Binder Synthesized with Copper Mine Tailings and Low-Calcium Copper Slag. J. Mater. Civ. Eng. 2019, 31, 04019156. [CrossRef]

95. Adam, A.A.; Horianto, X. The Effect of Temperature and Duration of Curing on the Strength of Fly Ash Based Geopolymer Mortar. Procedia Eng. 2014, 95, 410-414. [CrossRef]

96. Mo, B.-H.; Zhu, H.; Cui, X.-M.; He, Y.; Gong, S.-Y. Effect of curing temperature on geopolymerization of metakaolin-based geopolymers. Appl. Clay Sci. 2014, 99, 144-148. [CrossRef] 
97. Sun, Z.; Vollpracht, A. One year geopolymerisation of sodium silicate activated fly ash and metakaolin geopolymers. Cem. Concr. Compos. 2019, 95, 98-110. [CrossRef]

98. Villa, C.; Pecina, E.; Torres, R.; Gómez, L. Geopolymer synthesis using alkaline activation of natural zeolite. Constr. Build. Mater. 2010, 24, 2084-2090. [CrossRef]

99. Rovnaník, P. Effect of curing temperature on the development of hard structure of metakaolin-based geopolymer. Constr. Build. Mater. 2010, 24, 1176-1183. [CrossRef]

100. Okoye, F.; Durgaprasad, J.; Singh, N. Mechanical properties of alkali activated flyash/Kaolin based geopolymer concrete. Constr. Build. Mater. 2015, 98, 685-691. [CrossRef]

101. Samantasinghar, S.; Singh, S.P. Effect of synthesis parameters on compressive strength of fly ash-slag blended geopolymer. Constr. Build. Mater. 2018, 170, 225-234. [CrossRef]

102. Bernal, S.A.; Rodríguez, E.D.; de Gutiérrez, R.M.; Gordillo, M.; Provis, J.L. Mechanical and thermal characterisation of geopolymers based on silicate-activated metakaolin/slag blends. J. Mater. Sci. 2011, 46, 5477-5486. [CrossRef]

103. Lahoti, M.; Wong, K.K.; Tan, K.H.; Yang, E.-H. Effect of alkali cation type on strength endurance of fly ash geopolymers subject to high temperature exposure. Mater. Des. 2018, 154, 8-19. [CrossRef]

104. Zhang, H.Y.; Kodur, V.; Qi, S.L.; Cao, L.; Wu, B. Development of metakaolin-fly ash based geopolymers for fire resistance applications. Constr. Build. Mater. 2014, 55, 38-45. [CrossRef]

105. Lahoti, M.; Tan, K.H.; Yang, E.-H. A critical review of geopolymer properties for structural fire-resistance applications. Constr. Build. Mater. 2019, 221, 514-526. [CrossRef]

106. Ma, Y.; Hu, J.; Ye, G. The pore structure and permeability of alkali activated fly ash. Fuel 2013, 104, 771-780. [CrossRef]

107. Mehta, A.; Siddique, R. Strength, permeability and micro-structural characteristics of low-calcium fly ash based geopolymers. Constr. Build. Mater. 2017, 141, 325-334. [CrossRef]

108. Bai, C.; Colombo, P. Processing, properties and applications of highly porous geopolymers: A review. Ceram. Int. 2018, 44, 16103-16118. [CrossRef]

109. Nasvi, M.C.M.; Ranjith, P.G.; Sanjayan, J.; Bui, H. Effect of temperature on permeability of geopolymer: A primary well sealant for carbon capture and storage wells. Fuel 2014, 117, 354-363. [CrossRef]

110. Nergis, D.D.B.; Vizureanu, P.; Ardelean, I.; Sandu, A.V.; Corbu, O.C.; Matei, E. Revealing the Influence of Microparticles on Geopolymers' Synthesis and Porosity. Materials 2020, 13, 3211. [CrossRef] [PubMed]

111. Zhang, D.-W.; Zhao, K.-F.; Xie, F.-Z.; Li, H.; Wang, D.-M. Rheology and agglomerate structure of fresh geopolymer pastes with different Ms ratio of waterglass. Constr. Build. Mater. 2020, 250, 118881. [CrossRef]

112. Ahmari, S.; Zhang, L. Durability and leaching behavior of mine tailings-based geopolymer bricks. Constr. Build. Mater. 2013, 44, 743-750. [CrossRef]

113. Albitar, M.; Ali, M.S.M.; Visintin, P.; Drechsler, M. Durability evaluation of geopolymer and conventional concretes. Constr. Build. Mater. 2017, 136, 374-385. [CrossRef]

114. Nguyen, A.D.; Škvára, F. The influence of ambient pH on fly ash-based geopolymer. Cem. Concr. Compos. 2016, 72, 275-283. [CrossRef]

115. Noushini, A.; Castel, A.; Aldred, J.; Rawal, A. Chloride diffusion resistance and chloride binding capacity of fly ash-based geopolymer concrete. Cem. Concr. Compos. 2020, 105, 103290. [CrossRef]

116. Ekaputri, J.J.; Mutiara, I.S.; Nurminarsih, S.; Van Chanh, N.; Maekawa, K.; Setiamarga, D.H.E. The effect of steam curing on chloride penetration in geopolymer concrete. MATEC Web Conf. 2017, 138, 01019. [CrossRef]

117. Burduhos, D.; Vizureanu, P.; Andrusca, L.; Achitei, D.C. Performance of local fly ash geopolymers under different types of acids. IOP Conf. Ser. Mater. Sci. Eng. 2019, 572, 572. [CrossRef]

118. Ismail, I.; Bernal, A.S.; Provis, J.L.; Hamdan, S.; Van Deventer, J.S.J. Microstructural changes in alkali activated fly ash/slag geopolymers with sulfate exposure. Mater. Struct. 2013, 46, 361-373. [CrossRef]

119. Wu, Y.; Lu, B.; Bai, T.; Wang, H.; Du, F.; Zhang, Y.; Cai, L.; Jiang, C.; Wang, W. Geopolymer, green alkali activated cementitious material: Synthesis, applications and challenges. Constr. Build. Mater. 2019, 224, 930-949. [CrossRef]

120. Scrivener, K.L.; John, V.M.; Gartner, E.M. Eco-efficient cements: Potential economically viable solutions for a low-CO ${ }_{2}$ cementbased materials industry. Cem. Concr. Res. 2018, 114, 2-26. [CrossRef]

121. Zhang, Z.; Provis, J.; Reid, A.; Wang, H. Geopolymer foam concrete: An emerging material for sustainable construction. Constr. Build. Mater. 2014, 56, 113-127. [CrossRef]

122. Komnitsas, K. Potential of geopolymer technology towards green buildings and sustainable cities. Procedia Eng. 2011, 21, 1023-1032. [CrossRef]

123. Provis, J.L. Alkali-activated materials. Cem. Concr. Res. 2018, 114, 40-48. [CrossRef]

124. Peng, M.X.; Wang, Z.H.; Shen, S.H.; Xiao, Q.G. Synthesis, characterization and mechanisms of one-part geopolymeric cement by calcining low-quality kaolin with alkali. Mater. Struct. 2015, 48, 699-708. [CrossRef]

125. Nasvi, M.C.M.; Rathnaweera, T.D.; Padmanabhan, E. Geopolymer as well cement and its mechanical integrity under deep down-hole stress conditions: Application for carbon capture and storage wells. Géoméch. Geophys. Geo Energy Geo Resour. 2016, 2, 245-256. [CrossRef]

126. Panizza, M.; Natali, M.; Garbin, E.; Tamburini, S.; Secco, M. Assessment of geopolymers with Construction and Demolition Waste (CDW) aggregates as a building material. Constr. Build. Mater. 2018, 181, 119-133. [CrossRef] 
127. Ouffa, N.; Benzaazoua, M.; Belem, T.; Trauchessec, R.; Lecomte, A. Alkaline dissolution potential of aluminosilicate minerals for the geosynthesis of mine paste backfill. Mater. Today Commun. 2020, 24, 101221. [CrossRef]

128. Obenaus-Emler, R.; Falah, M.; Illikainen, M. Assessment of mine tailings as precursors for alkali-activated materials for on-site applications. Constr. Build. Mater. 2020, 246, 118470. [CrossRef]

129. Novais, R.M.; Seabra, M.; Labrincha, J. Porous geopolymer spheres as novel pH buffering materials. J. Clean. Prod. 2017, 143, 1114-1122. [CrossRef]

130. Novais, R.; Gameiro, T.; Carvalheiras, J.; Seabra, M.P.; Tarelho, L.A.D.C.; Labrincha, J.; Capela, I. High pH buffer capacity biomass fly ash-based geopolymer spheres to boost methane yield in anaerobic digestion. J. Clean. Prod. 2018, 178, 258-267. [CrossRef]

131. Krishna, R.; Shaikh, F.; Mishra, J.; Lazorenko, G.; Kasprzhitskii, A. Mine tailings-based geopolymers: Properties, applications and industrial prospects. Ceram. Int. 2021, 47, 17826-17843. [CrossRef]

132. Ahmari, S.; Zhang, L. Production of eco-friendly bricks from copper mine tailings through geopolymerization. Constr. Build. Mater. 2012, 29, 323-331. [CrossRef]

133. Shahedan, N.; Abdullah, M.; Mahmed, N.; Kusbiantoro, A.; Tammas-Williams, S.; Li, L.-Y.; Aziz, I.; Vizureanu, P.; Wysłocki, J.; Błoch, K.; et al. Properties of a New Insulation Material Glass Bubble in Geo-Polymer Concrete. Materials 2021, 14, 809. [CrossRef]

134. Hoy, M.; Horpibulsuk, S.; Arulrajah, A. Strength development of Recycled Asphalt Pavement-Fly ash geopolymer as a road construction material. Constr. Build. Mater. 2016, 117, 209-219. [CrossRef]

135. Guo, X.; Hu, W.; Shi, H. Microstructure and self-solidification/stabilization (S/S) of heavy metals of nano-modified CFA-MSWIFA composite geopolymers. Constr. Build. Mater. 2014, 56, 81-86. [CrossRef]

136. Waijarean, N.; Asavapisit, S.; Sombatsompop, K. Strength and microstructure of water treatment residue-based geopolymers containing heavy metals. Constr. Build. Mater. 2014, 50, 486-491. [CrossRef]

137. Sun, S.; Lin, J.; Zhang, P.; Fang, L.; Ma, R.; Quan, Z.; Song, X. Geopolymer synthetized from sludge residue pretreated by the wet alkalinizing method: Compressive strength and immobilization efficiency of heavy metal. Constr. Build. Mater. 2018, 170, 619-626. [CrossRef]

138. Chen, J.; Wang, Y.; Zhou, S.; Lei, X. Reduction/immobilization processes of hexavalent chromium using metakaolin-based geopolymer. J. Environ. Chem. Eng. 2017, 5, 373-380. [CrossRef]

139. Chen, J.; Wang, Y.; Wang, H.; Zhou, S.; Wu, H.; Lei, X. Detoxification/immobilization of hexavalent chromium using metakaolinbased geopolymer coupled with ferrous chloride. J. Environ. Chem. Eng. 2016, 4, 2084-2089. [CrossRef]

140. Vu, T.H.; Gowripalan, N. Mechanisms of Heavy Metal Immobilisation using Geopolymerisation Techniques-A review. J. Adv. Concr. Technol. 2018, 16, 124-135. [CrossRef]

141. Biondi, L.; Perry, M.; Vlachakis, C.; Wu, Z.; Hamilton, A.; McAlorum, J. Ambient Cured Fly Ash Geopolymer Coatings for Concrete. Materials 2019, 12, 923. [CrossRef]

142. Duan, P.; Yan, C.; Luo, W.; Zhou, W. A novel surface waterproof geopolymer derived from metakaolin by hydrophobic modification. Mater. Lett. 2016, 164, 172-175. [CrossRef]

143. McLellan, B.C.; Williams, R.; Lay, J.; van Riessen, A.; Corder, G.D. Costs and carbon emissions for geopolymer pastes in comparison to ordinary portland cement. J. Clean. Prod. 2011, 19, 1080-1090. [CrossRef]

144. Janardhanan, T.; Thaarrini, J.; Dhivya, S.; Dhivya, S. Comparative study on the production cost of geopolymer and conventional concretes. Int. J. Civ. Eng. Res. 2016, 7, 117-124.

145. Wattanachai, P.; Suwan, T. Strength of Geopolymer Cement Curing at Ambient Temperature by Non-Oven Curing Approaches: An Overview. In Proceedings of the IOP Conference Series: Materials Science and Engineering, Busan, Korea, 25-27 August 2017; Volume 212, p. 012014. [CrossRef]

146. Xie, T.; Ozbakkaloglu, T. Behavior of low-calcium fly and bottom ash-based geopolymer concrete cured at ambient temperature. Ceram. Int. 2015, 41, 5945-5958. [CrossRef]

147. Mahmoodi, O.; Siad, H.; Lachemi, M.; Dadsetan, S.; Sahmaran, M. Optimization of brick waste-based geopolymer binders at ambient temperature and pre-targeted chemical parameters. J. Clean. Prod. 2020, 268, 122285. [CrossRef]

148. Suwan, T.; Fan, M. Effect of manufacturing process on the mechanisms and mechanical properties of fly ash-based geopolymer in ambient curing temperature. Mater. Manuf. Process. 2016, 32, 461-467. [CrossRef]

149. Tennakoon, C.; Nicolas, R.S.; Sanjayan, J.; Shayan, A. Thermal effects of activators on the setting time and rate of workability loss of geopolymers. Ceram. Int. 2016, 42, 19257-19268. [CrossRef]

150. Bong, S.H.; Xia, M.; Nematollahi, B.; Shi, C. Ambient temperature cured 'just-add-water' geopolymer for 3D concrete printing applications. Cem. Concr. Compos. 2021, 121, 104060. [CrossRef]

151. Bong, S.H.; Nematollahi, B.; Nazari, A.; Xia, M.; Sanjayan, J.G. Fresh and hardened properties of 3D printable geopolymer cured in ambient temperature. In Proceedings of the RILEM International Conference on Concrete and Digital Fabrication, Zurich, Switzerland, 10-12 September 2018; pp. 3-11.

152. Kashani, A. Optimisation of Mixture Properties for 3D Printing of Geopolymer Concrete. In Proceedings of the 35th International Symposium on Automation and Robotics in Construction (ISARC); International Association for Automation and Robotics in Construction (IAARC), Berlin, Germany, 20-25 July 2018; Volume 2018, pp. 251-258.

153. Vijai, K.; Kumutha, R.; Vishnuram, B.G. Effect of types of curing on strength of geopolymer concrete. Int. J. Phys. Sci. 2010, 5, 1419-1423.

154. Nurruddin, M.F.; Haruna, S.; Mohammed, B.S.; Galal, I. International Journal of Advanced and Applied Sciences Methods of curing geopolymer concrete: A review. Int. J. Adv. Appl. Sci. 2018, 5, 31-36. [CrossRef] 
155. Shah, S.F.A.; Chen, B.; Oderji, S.Y.; Haque, M.A.; Ahmad, M.R. Improvement of early strength of fly ash-slag based one-part alkali activated mortar. Constr. Build. Mater. 2020, 246, 118533. [CrossRef]

156. Khalil, M.G.; Elgabbas, F.; El-Feky, M.S.; El-Shafie, H. Performance of geopolymer mortar cured under ambient temperature. Constr. Build. Mater. 2020, 242, 118090. [CrossRef]

157. Nath, P.; Sarker, P. Geopolymer concrete for ambient curing condition. In Proceedings of the Australasian Structural Engineering Conference, Perth, Australia, 11-13 July 2012; pp. 1-9.

158. Khan, M.Z.N.; Shaikh, F.U.A.; Hao, Y.; Hao, H. Synthesis of high strength ambient cured geopolymer composite by using low calcium fly ash. Constr. Build. Mater. 2016, 125, 809-820. [CrossRef]

159. Oyebisi, S.O.; Owolabi, E.F.; Owamah, H.I.; Oluwafemi, J.O.; Ayanbisi, O.W. Strength Prediction of GPC using Alkali pH, Salinity, Temperature, and Conductivity as Continuous Predictors. IOP Conf. Ser. Mater. Sci. Eng. 2021, 1107, 012145. [CrossRef]

160. Giasuddin, H.M.; Sanjayan, J.G.; Ranjith, P. Strength of geopolymer cured in saline water in ambient conditions. Fuel 2013, 107, 34-39. [CrossRef]

161. Ding, Y.; Shi, C.-J.; Li, N. Fracture properties of slag/fly ash-based geopolymer concrete cured in ambient temperature. Constr. Build. Mater. 2018, 190, 787-795. [CrossRef]

162. Nath, P.; Sarker, P. Effect of GGBFS on setting, workability and early strength properties of fly ash geopolymer concrete cured in ambient condition. Constr. Build. Mater. 2014, 66, 163-171. [CrossRef]

163. Ghafoor, M.T.; Khan, Q.S.; Qazi, A.U.; Sheikh, M.N.; Hadi, M. Influence of alkaline activators on the mechanical properties of fly ash based geopolymer concrete cured at ambient temperature. Constr. Build. Mater. 2021, 273, 121752. [CrossRef]

164. Al-Zboon, K.; Al-Harahsheh, M.; Hani, F.B. Fly ash-based geopolymer for Pb removal from aqueous solution. J. Hazard. Mater. 2011, 188, 414-421. [CrossRef]

165. Gharzouni, A.; Joussein, E.; Samet, B.; Baklouti, S.; Rossignol, S. Effect of the reactivity of alkaline solution and metakaolin on geopolymer formation. J. Non Cryst. Solids 2015, 410, 127-134. [CrossRef]

166. Nematollahi, B.; Sanjayan, J. Effect of different superplasticizers and activator combinations on workability and strength of fly ash based geopolymer. Mater. Des. 2014, 57, 667-672. [CrossRef]

167. Rattanasak, U.; Chindaprasirt, P. Influence of $\mathrm{NaOH}$ solution on the synthesis of fly ash geopolymer. Miner. Eng. 2009, 22, 1073-1078. [CrossRef]

168. Liew, Y.-M.; Heah, C.-Y.; Mustafa, A.B.M.; Kamarudin, H. Structure and properties of clay-based geopolymer cements: A review. Prog. Mater. Sci. 2016, 83, 595-629. [CrossRef]

169. Samarakoon, M.; Ranjith, P.; Rathnaweera, T.; Perera, S. Recent advances in alkaline cement binders: A review. J. Clean. Prod. 2019, 227, 70-87. [CrossRef]

170. Görhan, G.; Kürklü, G. The influence of the $\mathrm{NaOH}$ solution on the properties of the fly ash-based geopolymer mortar cured at different temperatures. Compos. Part B Eng. 2014, 58, 371-377. [CrossRef]

171. Budh, C.D.; Warhade, N.R. Effect of molarity on compressive strength of geopolymer mortar. Int. J. Civ. Eng. Res. 2014, 5, 2278-3652.

172. Oyebisi, S.; Ede, A.; Ofuyatan, O.; Oluwafemi, J.; Olutoge, F. Modeling of hydrogen potential and compressive strength of geopolymer concrete. Int. J. Civ. Eng. Technol. 2018, 9, 671-679.

173. Loh, P.Y.; Shafigh, P.; Katman, H.Y.B.; Ibrahim, Z.; Yousuf, S. pH Measurement of Cement-Based Materials: The Effect of Particle Size. Appl. Sci. 2021, 11, 8000. [CrossRef]

174. He, P.; Wang, M.; Fu, S.; Jia, D.; Yan, S.; Yuan, J.; Xu, J.; Wang, P.; Zhou, Y. Effects of Si/Al ratio on the structure and properties of metakaolin based geopolymer. Ceram. Int. 2016, 42, 14416-14422. [CrossRef]

175. Hajimohammadi, A.; van Deventer, J.S. Dissolution behaviour of source materials for synthesis of geopolymer binders: A kinetic approach. Int. J. Miner. Process. 2016, 153, 80-86. [CrossRef]

176. Hajimohammadi, A.; Provis, J.L.; van Deventer, J.S.J. Effect of Alumina Release Rate on the Mechanism of Geopolymer Gel Formation. Chem. Mater. 2010, 22, 5199-5208. [CrossRef]

177. Thokchom, S.; Ghosh, P.; Ghosh, S. Performance of Fly ash Based Geopolymer Mortars in Sulphate Solution. J. Eng. Sci. Technol. Rev. 2010, 3, 36-40. [CrossRef]

178. Abdullah, M.M.A.; Kamarudin, H.; Bnhussain, M.; Nizar, I.K.; Rafiza, A.; Zarina, Y. The Relationship of NaOH Molarity, $\mathrm{Na}_{2} \mathrm{SiO}_{3} / \mathrm{NaOH}$ Ratio, Fly Ash/Alkaline Activator Ratio, and Curing Temperature to the Strength of Fly Ash-Based Geopolymer. Adv. Mater. Res. 2011, 328-330, 1475-1482. [CrossRef]

179. Abdullah, M.M.A.B.; Kamarudin, H.; Nizar, I.K.; Bnhussain, M.; Zarina, Y.; Rafiza, A. Correlation between $\mathrm{Na}_{2} \mathrm{SiO}_{3} / \mathrm{NaOH}^{\mathrm{Ratio}}$ and Fly Ash/Alkaline Activator Ratio to the Strength of Geopolymer. Adv. Mater. Res. 2011, 341-342, 189-193. [CrossRef]

180. Ishwarya, G.; Singh, B.; Deshwal, S.; Bhattacharyya, S. Effect of sodium carbonate/sodium silicate activator on the rheology, geopolymerization and strength of fly ash/slag geopolymer pastes. Cem. Concr. Compos. 2019, 97, 226-238. [CrossRef]

181. Ahmari, S.; Parameswaran, K.; Zhang, L. Alkali Activation of Copper Mine Tailings and Low-Calcium Flash-Furnace Copper Smelter Slag. J. Mater. Civ. Eng. 2015, 27, 04014193. [CrossRef]

182. Shadnia, R.; Zhang, L. Experimental Study of Geopolymer Synthesized with Class F Fly Ash and Low-Calcium Slag. J. Mater. Civ. Eng. 2017, 29, 04017195. [CrossRef]

183. Jang, J.; Lee, N.; Lee, H. Fresh and hardened properties of alkali-activated fly ash/slag pastes with superplasticizers. Constr. Build. Mater. 2014, 50, 169-176. [CrossRef] 


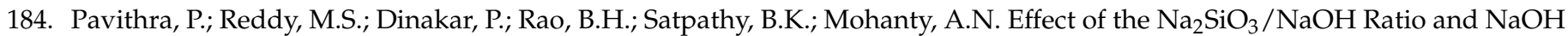
Molarity on the Synthesis of Fly Ash-Based Geopolymer Mortar. In Proceedings of the Geo-Chicago 2016, Chicago, IL, USA, 14-18 August 2016; pp. 336-344.

185. Mortar, N.A.M.; Kamarudin, H.; Rafiza, R.A.; Meor, T.; Rosnita, M. Compressive Strength of Fly Ash Geopolymer Concrete by Varying Sodium Hydroxide Molarity and Aggregate to Binder Ratio. IOP Conf. Ser. Mater. Sci. Eng. 2020, 864, 012037. [CrossRef]

186. Opiso, E.M.; Tabelin, C.B.; Maestre, C.V.; Aseniero, J.P.J.; Park, I.; Villacorte-Tabelin, M. Synthesis and characterization of coal fly ash and palm oil fuel ash modified artisanal and small-scale gold mine (ASGM) tailings based geopolymer using sugar mill lime sludge as Ca-based activator. Heliyon 2021, 7, e06654. [CrossRef] [PubMed]

187. Phetchuay, C.; Horpibulsuk, S.; Suksiripattanapong, C.; Chinkulkijniwat, A.; Arulrajah, A.; Disfani, M.M. Calcium carbide residue: Alkaline activator for clay-fly ash geopolymer. Constr. Build. Mater. 2014, 69, 285-294. [CrossRef]

188. Xie, J.; Kayali, O. Effect of initial water content and curing moisture conditions on the development of fly ash-based geopolymers in heat and ambient temperature. Constr. Build. Mater. 2014, 67, 20-28. [CrossRef]

189. Lahoti, M.; Yang, E.-H.; Tan, K.H. Influence of Mix Design Parameters on Geopolymer Mechanical Properties and Microstructure. In Advances in Bioceramics and Porous Ceramics II; Wiley: Hoboken, NJ, USA, 2017; Volume 37, pp. 21-33.

190. Hardjito, D.; Wallah, S.E.; Sumajouw, D.M.; Rangan, B.V. On the development of fly ash-based geopolymer concrete. Mater. J. 2004, 101, 467-472.

191. Gado, R.A.; Hebda, M.; Łach, M.; Mikuła, J. Alkali Activation of Waste Clay Bricks: Influence of The Silica $\mathrm{Modulus} \mathrm{SiO}_{2} / \mathrm{Na}_{2} \mathrm{O}$, $\mathrm{H}_{2} \mathrm{O} / \mathrm{Na}_{2} \mathrm{O}$ Molar Ratio, and Liquid/Solid Ratio. Materials 2020, 13, 383. [CrossRef]

192. Pouhet, R.; Cyr, M.; Bucher, R. Influence of the initial water content in flash calcined metakaolin-based geopolymer. Constr. Build. Mater. 2019, 201, 421-429. [CrossRef]

193. Luna-Galiano, Y.; Leiva, C.; Villegas, R.; Arroyo, F.; Vilches, L.; Fernández-Pereira, E.C. Carbon fiber waste incorporation in blast furnace slag geopolymer-composites. Mater. Lett. 2018, 233, 1-3. [CrossRef]

194. Mu, S.; Liu, J.; Lin, W.; Wang, Y.; Liu, J.; Shi, L.; Jiang, Q. Property and microstructure of aluminosilicate inorganic coating for concrete: Role of water to solid ratio. Constr. Build. Mater. 2017, 148, 846-856. [CrossRef]

195. Yip, C.K.; Lukey, G.C.; Provis, J.; Van Deventer, J.S. Effect of calcium silicate sources on geopolymerisation. Cem. Concr. Res. 2008, 38, 554-564. [CrossRef]

196. Phoo-Ngernkham, T.; Maegawa, A.; Mishima, N.; Hatanaka, S.; Chindaprasirt, P. Effects of sodium hydroxide and sodium silicate solutions on compressive and shear bond strengths of FA-GBFS geopolymer. Constr. Build. Mater. 2015, 91, 1-8. [CrossRef]

197. Tian, X.; Zhang, H.; Zhang, T.; Fernández, C.A. Alkali-activated copper tailings-based pastes: Compressive strength and microstructural characterization. J. Mater. Res. Technol. 2020, 9, 6557-6567. [CrossRef]

198. Pacheco-Torgal, F.; Jalali, S.; Gomes, J.C. Utilization of mining wastes to produce geopolymer binders. In Geopolymers Structure, Processing, Properties and Industrial Applications; Woodhead Publishing: Sawston, UK, 2009; pp. 267-293. [CrossRef]

199. Oderji, S.Y.; Chen, B.; Ahmad, M.R.; Shah, S.F.A. Fresh and hardened properties of one-part fly ash-based geopolymer binders cured at room temperature: Effect of slag and alkali activators. J. Clean. Prod. 2019, 225, 1-10. [CrossRef]

200. Antoni; Satria, J.; Sugiarto, A.; Hardjito, D. Effect of Variability of Fly Ash Obtained from the Same Source on the Characteristics of Geopolymer. MATEC Web Conf. 2017, 97, 1026. [CrossRef]

201. Fang, G.; Ho, W.K.; Tu, W.; Zhang, M. Workability and mechanical properties of alkali-activated fly ash-slag concrete cured at ambient temperature. Constr. Build. Mater. 2018, 172, 476-487. [CrossRef]

202. Wan, X.; Hou, D.; Zhao, T.; Wang, L. Insights on molecular structure and micro-properties of alkali-activated slag materials: A reactive molecular dynamics study. Constr. Build. Mater. 2017, 139, 430-437. [CrossRef]

203. Hou, D.; Li, Z.; Zhao, T. Reactive force field simulation on polymerization and hydrolytic reactions in calcium aluminate silicate hydrate (C-A-S-H) gel: Structure, dynamics and mechanical properties. RSC Adv. 2015, 5, 448-461. [CrossRef]

204. Kumar, S.; Kumar, R.; Mehrotra, S.P. Influence of granulated blast furnace slag on the reaction, structure and properties of fly ash based geopolymer. J. Mater. Sci. 2010, 45, 607-615. [CrossRef]

205. Xu, C.; Andre, S.; Leslie, J. Effects of Calcium on Setting Mechanism of Metakaolin-based Geopolymer. Int. J. Lab. Hematol. 2016, 38, 42-49. [CrossRef]

206. Antoni; Wijaya, S.W.; Hardjito, D. Factors Affecting the Setting Time of Fly Ash-Based Geopolymer. Mater. Sci. Forum 2016, 841, 90-97. [CrossRef]

207. Komnitsas, K.; Zaharaki, D.; Bartzas, G. Effect of sulphate and nitrate anions on heavy metal immobilisation in ferronickel slag geopolymers. Appl. Clay Sci. 2013, 73, 103-109. [CrossRef]

208. Silwamba, M.; Ito, M.; Hiroyoshi, N.; Tabelin, C.B.; Fukushima, T.; Park, I.; Jeon, S.; Igarashi, T.; Sato, T.; Nyambe, I.; et al. Detoxification of lead-bearing zinc plant leach residues from Kabwe, Zambia by coupled extraction-cementation method. J. Environ. Chem. Eng. 2020, 8, 104197. [CrossRef]

209. Tabelin, C.B.; Silwamba, M.; Paglinawan, F.C.; Mondejar, A.J.S.; Duc, H.G.; Resabal, V.J.; Opiso, E.M.; Igarashi, T.; Tomiyama, S.; Ito, M.; et al. Solid-phase partitioning and release-retention mechanisms of copper, lead, zinc and arsenic in soils impacted by artisanal and small-scale gold mining (ASGM) activities. Chemosphere 2020, 260, 127574. [CrossRef]

210. Tchadjie, L.N.; Ekolu, S.O. Enhancing the reactivity of aluminosilicate materials toward geopolymer synthesis. J. Mater. Sci. 2018, 53, 4709-4733. [CrossRef] 